\title{
ОРНАМЕНТ ПОЗДНЕСРЕДНЕВЕКОВЫХ И РЕНЕССАНСНЫХ ИЗРАЗЦОВ ПОДЛЯШЬЯ - ЗЕМЕЛЬ ЗАПАДНОЙ РУСИ НАХОДЯЩИЕСЯ В СОСТАВЕ ВЕЛИКОГО КНЯЖЕСТВА ЛИТОВСКОГО
}

\author{
Ирина Таранта \\ Muzeum Podlaskie w Białymstoku, Dział Archeologii, Białystok \\ e-mail: i.taranta@muzeum.bialystok.pl $\mid$ Научный обзор \\ Получили: 25. 3. 2021. УДК: 738.04(470-89-15)"14/15" \\ Принято: 9. 6. 2021. 904:7.04(470-89-15)"14/15” 069.5(438)
}

\begin{abstract}
Аннотация: Орнамент это особая широкая область искусства, весьма интересная и серьёзная по своему историческому значению и по своему близкому, разнообразному соотнотению с другими, выстими изящными искусствами (Лорени 1898). Если отнестись к этому глубже, то мы поймём, что орнаменты не случайныля и произвольныя украшения, а подчиненнье, во первых духу и характеру развития искусства каждой народности, а во вторых своему назначению (Лорени 1898). Анализ декоративных мотивов позднесредневековых и ренессансных изразиов Подляшья, на землях Западной Руси находящиеся в составе Великого княжества Литовского (современная восточная часть Подляшского воеводства, Польша) делает возможным анализ воздействий, сообщения и влияния цеентров Восточной и Западной Европьл. Историко-культурная специфика этих земель в период позднего Средневековья - эпоху Возрождения (вторая половина XV века - третья треть XVI века), когда существовали две ичивилизации: византийско-русская и латинская, имела огромное влияние на тематику декоративного искусства изразцов, которые были не только украшением о чисто художественных качествах, но отображением мира мысли и чувств человека в его двух главных сферах: сакрум и профанум. Изразиы были найдены в разных иентрах: городах (Бельск, Дрогичын, Сураж, Тыкоцин), замке (Мельник), монастырях (православный Супрасьль и католический Тыкочин) и шляхетской усадьбе (Дубно).
\end{abstract}

Ключевые слова: византийско-русский орнамент, русский орнамент, готический орнамент, Западная Русь, Подляшское воеводство

Печные изразцы появились в XIII веке прежде всего в странах Европы о более прохладном климате и распространились на территории современной Польши и Беларуси в очередном столетии (Dymek 1995, 9; Заяц 2001, 319). Самые старые печи были построены из сосудообразных изразцов, горшкообразных и мискообразных. Новый тип изделий - коробчатые изразцы, состоящие из лицевой пластины и прилепленной румпы, возник в 
$\mathrm{XV}$ веке. Печь, кроме утилитарной функции, исполняла декоративную роль и украшала интерьер камеры жилища. На лицевых пластинах появляются высокохудожественные, рельефные, разнообразны орнаменты. Анализ декоративных мотивов изразцов эпохи позднего Средневековья, найденных на землях Западной Руси находящиеся в составе Великого княжества Литовского (современная восточная часть Подляшского воеводства, Польша) делает возможным анализ воздействий, сообщения и влияния центров Восточной и Западной Европы. Историко-культурная специфика этих земель в период позднего Средневековья - эпоху Возрождения (вторая половина XV века - третья треть XVI века), когда существовали две цивилизации: византийско-русская и латинская, имела огромное влияние на тематику декоративного искусства изразцов, которые были не только украшением о чисто художественных качествах, но отображением мира мысли и чувств человека в его двух главных сферах: сакрум и профанум.

Выбор представляемого материала был продиктован местом изыскания (территория исторических земель Подляшья), состоянием сохранения, тематически разнообразным орнаментом (религиозным, геральдическим, архитектоническим и прочие), и хронологией - временем (вторая половина XV - третья треть XVI вв.). Изразцы были найдены в разных центрах: городах (Бельск, Дрогичын, Сураж, Тыкоцин), замке (Мельник), монастырях (православный Супрасьль и католический Тыкоцин) и шляхетской усадьбе (Дубно). Они являются одними из наиболее многочисленных и интересных материалов этого периода, находящихся в коллекции Подляшского Музея в Белостоке, в Отделе Археологии.

\section{Краткая историческая справка}

Города Дрогичин, Бельск, Мельник, Сураж, Тыкоцин являются одними из самих древних городов в современном Подляшском воеводстве. В Средневековье Дрогицкий, Бельский, Мельницкий, Сураский городища находились в Руси, в Галицко-Волынском княжестве, в Берестейской земли (рис. 1). В начале XIV века, по истечении рода Романовичей - волынской ветви рода Рюриковичей, о русские земли воевали поляки, венгры и литовцы (Bukowski i Michaluk 2018, 9). Берестейская земля нашлась в западной части Великого княжества Литовского. В течении XIV и следующего столетия эти территории были предметом многих вооружённых конфликтов между тевтонскими рыцарями, литовцами и мазовшанами (Bukowski i Michaluk 2018, 9-11).

В 1385 годе великий князь литовский Владислав II Ягайло заключил унию Литвы и Польши, принял крещение в латинском обряде и женился на 


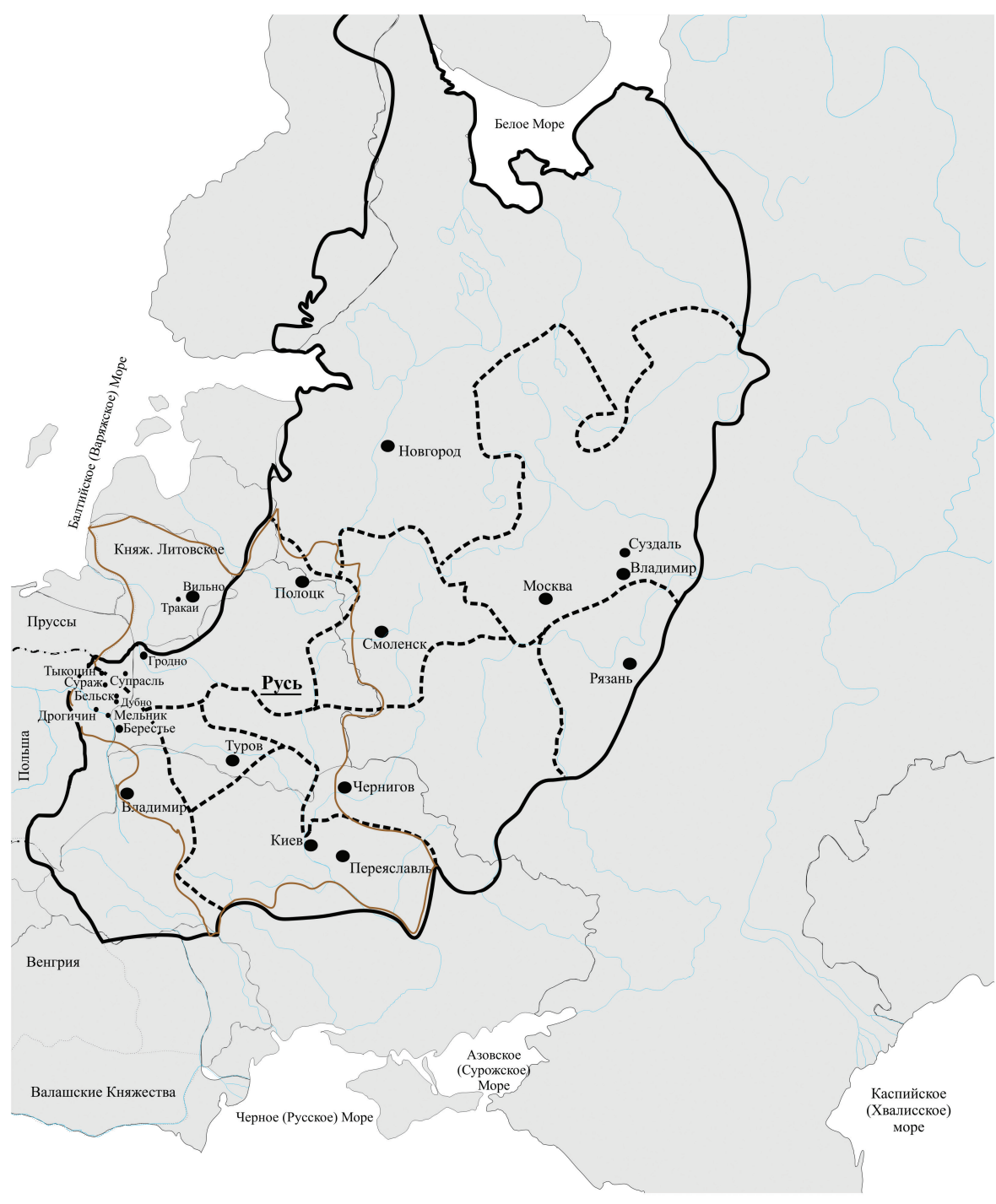

Рис. 1. Картина Восточной Европы: 1 - граница Руси в раннем Средневековье в 1237 году; 2 - границы княжеств и королевств в 1237 году; 3 - граница Великого княжества Литовского; 4 - границы современных государств; 5 - реки (https://pl.wikipedia.org/wiki/ Plik:Kievan_Rus_in_1237, доступ: 18. 03. 2021)

Сл. 1. Карта Источне Европе: 1 - граница Русије у раном средњем веку 1237. године; 2 - границе кнежевина и царстава 1237. године; 3 - граница Великог војводства Литваније; 4 - границе модерних држава; 5 - реке

(https://pl.wikipedia.org/wiki/ Plik:Kievan_Rus_in_1237, приступљено: 18. 03. 2021) 
королеве Польши Ядвиге (Bukowski i Michaluk 2018, 10). Последствиями этого события было принятие новых образцов юридических, административных и организационных, рост значения Римско-католической церкви в государстве, преуменьшение роли Православной церкви и ограничение прав православной элиты (Bukowski i Michaluk 2018, 10). В результате решений унии в Городле, заключённой в 1413 г., полновластие принадлежало католической управляющей элите, зато русские, православные можновладцы были столкнуты на предел (Gil 2015, 9).

В начале XV века в Великом княжестве Литовским провели администраторскую реформу государства, создавая очень обширные воеводства. Земли над Бугом, Лесной, Нарвой и Бебжой вошли в 1413 году в состав огромного Троксого воеводства с центром городом Троки. В 1520 году был выставлен акт установления нового, Подляшского воеводства с центром в Дрогичыне. В его составе нашлись Берестейская, Дрогицкая, Мельницкая, Бельская, Каменецкая и Кобрынская земли (Bukowski i Michaluk 2018, 11). Монастырь в Супрасле остался в Трокском воеводстве.

Шляхетская усадьба в Дубне (недалеко Бельска) была упоминаемая первый раз в 1506 году. В 1512 году Иван Сапега - основатель коденской линии рода и первый подляшский воевода, маршалок господарский, витебский воевода, поменялся на владения в дрогиченской земле и получил во владение Дубно (Rachuba 2013, 32-33).

Название „Подльяше” (Подляшье) для этой территории начало распространяться в конце XV века в канцелярских документах Великого княжества Литовского (Kołodziejczyk 2007, 309). Относилось оно к южным частям Берестейской земли и обозначало соседствую территорию с жителями Короны королевства Польского - Ляхами (Bukowski i Michaluk 2018, 7).

Следующей значимой стадией развития было решение сделанное на обрядах виленского сейма в 1565-1566 годах. В это время создано Берестейское воеводство с Берестейской, Каменецкой, Кобрынской земель, Пинского округа, с центром в Бересте, а Подляшское воеводство уменьшилось до трёх земель: Дрогицкой, Мельницкой и Бельской. Воеводство по-прежнему осталось дифференцированное смотря на этнос и вероисповедание с перевесом русского населения на востоке, мазовшанского на западе, а на севере жили поселенцы русские, мазовшанские и литовские (Bukowski i Michaluk 2018, 11-12). Важными городами были столицы земель: расположенные над Бугом Дрогичын и Мельник, на сухопутных путях в разветвлении рек Белой и Любки Бельск, и другие Браньск, Сураж, Тыкоцин. Православный монастырь в Супрасьле, который был основан в 1500 году, остался в Трокском 
воеводстве, в Гродненском повете. В 1569 году вследствие решения Люблинской унии Подляское воеводство было инкорпорировано в Корону королевства Польского. Три года позже умер последний представитель династии Ягеллонов и последний польский король и великий князь литовский, получивши корону в результате наследства - Сигизмунд II Август.

\section{Краткий технологический анализ}

Коробчатые изразцы формировались из красножгущихся глин, с примесью мелкозернистого и среднезернистого песка, реже карбонатных пород. К их производству использовали глину о соответствующей пластичности, полученную через добавление примеси, которой качество и пропорция не затирали отпечатанного рисунка (Dymek 1995, 54). Аккуратная выработка массы предназначенной для производства лицевой пластины может свидетельствовать о привязывании большого значения к формированию пластин в целях получения как наиболее хорошего иконографического представления (Dąbrowska 1987, 183; Dymek 1995, 55). С процедурой отбивания декора в подготовленной прежде форме связаны три основные категории следов оставленных на обратной стороне лица изразца как следы пальцев, ткани и сглаживания. Места соединения лицевой пластины с румпой было укреплено планками: внешнюю и внутреннюю, носящих следы растирания и сглаживания.

\section{Изразцы с религиозными сюжетами}

В иконографии обсуждённой коллекции изразцов важное место занимают религиозные сюжеты, инспирированные Священным Писанием (в частности Евангелием святого Иоанна и Апокалипсисом), которого знакомство было на высоком уровне познания. Христианская символика была передана языком искусства на глиняные пластины этих изделий. Во византийско-русским, русским, сербским искусствах христианские идеи и сюжеты впрягают искусство в службу религии. Благодаря точному приспособлению орнамента к конкретному типу изразца (стенные, карнизные, поясовые), декор гармонично вписывается в структуру каждого конструкционного элемента печи.

Стилистика и тематика изображений изразцов найденных в Дрогичыне, на территории участка с церковью святого Николая (возникла перед 1626 г.) и в наиболее древней части раннесредневекового и средневекового города, монастыря в Супрасьле, и на одним из городских земельных участков Тыкоцина, однозначно показывают на византийско-русское, русское и сербское искусства. Орнамент создают типичное для неё симметрические, 
повторяемые, точно выполненные и преисполненные глубиной христианской символики композиции из прекрасно стилизованной виноградной лозой с гроздьями ягод (рис. 2: 2), мотивами: креста - символ Иисуса Христа (рис. 3, 4: 3), Древа Жизни (рис. 5: 1, 6, 7:1), павлина - Воскресение, трилистника - Пресвятая Троица (рис. 5: 1) и Цветка Жизни (рис. 8: 1).

На датированным на первую половину XVI века изразце из Супраского монастыря находится повторяющийся мотив спирально свергнутой ветки виноградной лозы с гроздью: три пластические ягоды уложенные в треугольник, символизирующие учеников Иисуса Христа (рис. 2: 2). „Я есмь истинная виноградная лоза, а Отец Мой - виноградарь. Всякую у Меня ветвь, не приносящую плода, Он отсекает; и всякую, приносящую плод, очищает, чтобы более принесла плода.[...] Пребудьте во Мне, и Я в вас. Как ветвь не может приносить плода сама собою, если не будет на лозе: так и вы, если не будете во Мне. Я есмь лоза, а вы ветви; кто пребывает во Мне, и я в нем, тот приносит много плода; ибо без Меня не можете делать ничего" (Евангелие от Иоанна 15, 1-5). Мотив виноградной лозы с гроздьями ягод это один из наиболее часто встреченных иконографических представлений во византийско-русским, русским и сербским искусствах. Мотив трёх ягод появляется на ризах священных мучеников Юстина, Василия, Ореста, Юлиты, Георгия (Pokryszkin 2019, 111, 120-1, pис. 13, 21-2; Motowicka, Zalewska $2019,352-4,370)$, написанных на византийско-русских и сербских фресках с половины XVI века авторства сербского художника Нектария, украшающих Супраский храм Благовещения Пресвятой Богородицы, на русской иллюминированной рукописи в книге Патерик сводный, сигн. 13 „Книги 2 Отеченики из Паисиевым житием новописанныи", датированы пред 1532 годом, находящиеся в Супраской библиотеке в XVI веке (Mironowicz 2014, 194-6). Этот мотив украшает русские Псалтиры с XIV столетия, находящихся в конце XIX века в Императорской Публичной библиотеке (Лоренц 1898, табл. 35: 5) и наряд сербского царья Стефана Уроша IV Душана из родословного древа Неманичей (Лоза Неманичей), розписаной в монастирье Высокие Дечаны в 1386/1387 годах (Serbian Artistic Heritage 2017, 386-387).

Очередными важными представлениями, известными как с Старого так и Нового Завета, являются Древо Жизни - символ бессмертия (рис. 5: 1, 6, 7: 1), и находящийся под ним павлины - обозначающие Воскресение или голуби - символ души (рис. 5: 1). Древо Жизни было описано в первой и последней книге Библии. „И насадил Господь Бог рай в Едеме на востоке, и поместил там человека, которого создал. И произрастил Господь Бог из земли всякое дерево, приятное на вид и хорошее для 

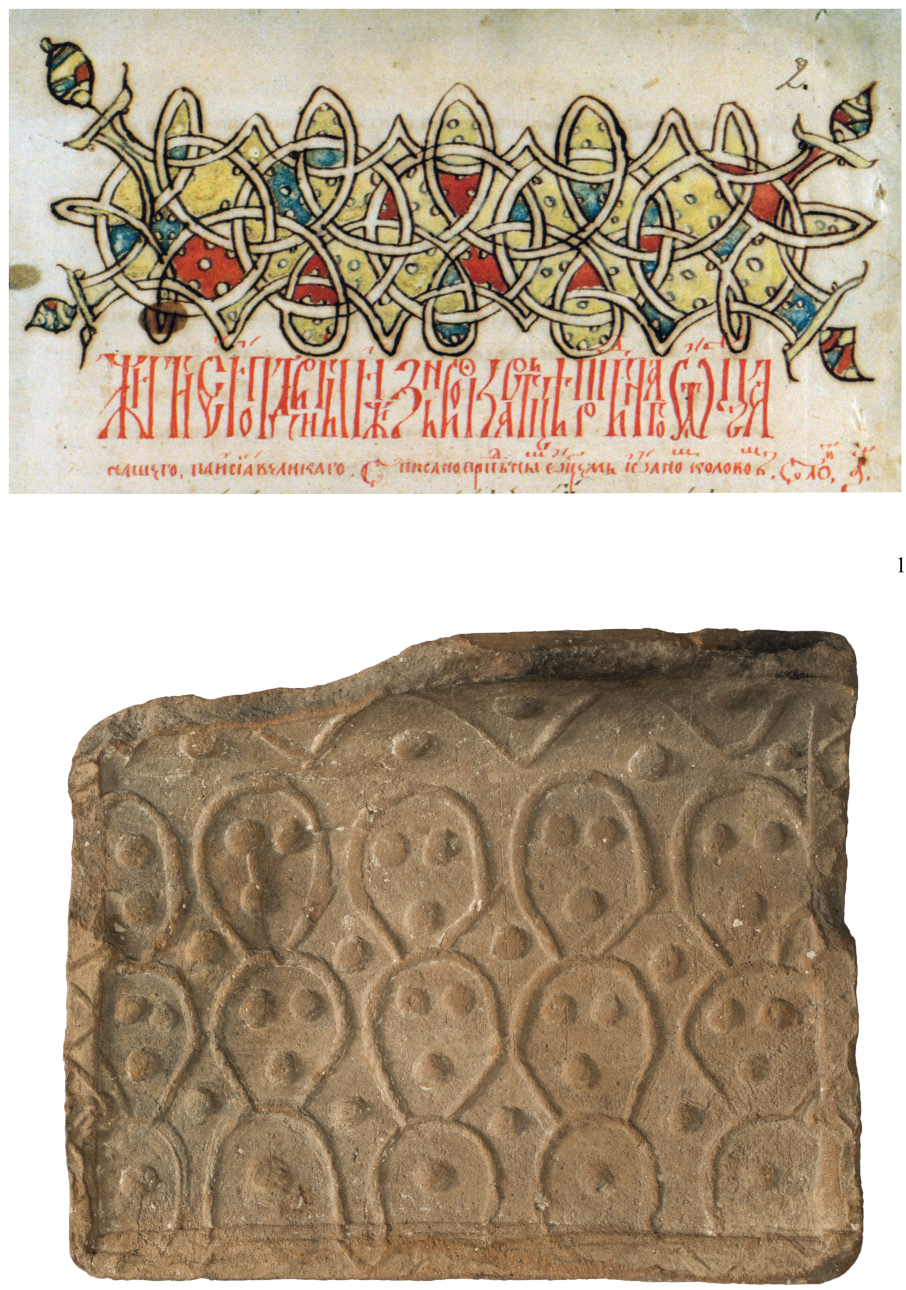

Рис. 2. Супрасьль. 1. Иллюминированная рукопись в книге Патерик сводный, сигн. 13 „Книги 2 Отеченики из Паисиевым житием новописанныи”, датированы пред 1532 годом, находящиеся в Супраской монастырской библиотеке

в 16. веке. 2. Изразец из первой половины 16. века. Размер - высота: 159 мм; ширина: 195 мм; глубина: 51 мм

Сл. 2. Супрасл. 1. Илуминирани рукопис у књизи Патерик консолидовани, сигн. 13 „Книги 2 Отеченики из Паисиевым житием новописанныи”, датиране пре 1532. године, похрањене у библиотеци манастира Супраск у 16. веку. 2. Плочица из прве половине 16. века. Димензије - висина: 159 мм; ширина: 195 мм; дубина: 51 мм 

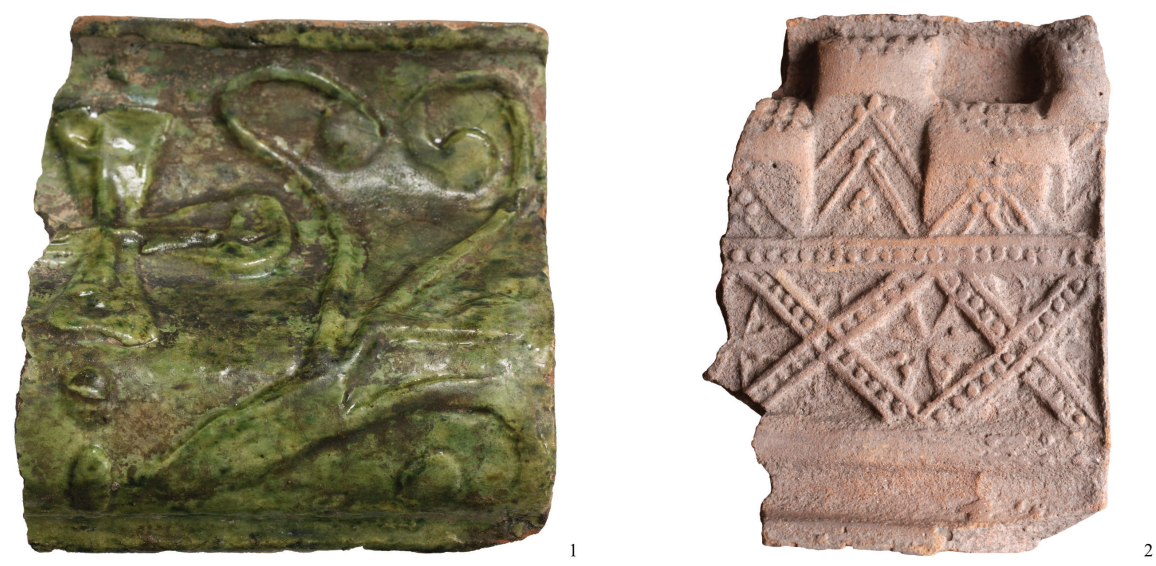

Рис. 3. 1. Дрогичин, изразец из 16. века. Размер - высота: 117 мм; ширина: 115 мм; глубина: 59-94 мм. 2. Дубно около Бельска, изразец из второй половины 16. века. Размер - высота: 142 мм; ширина: 107 мм (Garas, Karwowska 2013, 217, рис. 5)

Сл. 3. 1. Дрогичин, плочица из 16. века. Димензије - висина: 117 мм; ширина: 115 мм; дубина: 59-94 мм. 2. Дубно близу Белска, плочица из друге половине 16. века. Димензије - висина: 142 мм; ширина: 107 мм (Garas, Karwowska 2013, 217, сл. 5)

пищи, и дерево жизни посреди рая, и древо познания добра и зла" (Книга Бытия 2, 8-9). „И сказал Господь Бог: вот, Адам стал как один из Нас, зная добро и зло; и теперь как бы не простер руки своей и не взял также от дерева жизни, и не вкусил, и не стал жить вечно. (...) И изгнал Адама, и поставил на востоке у сада Едемского Херувима ипламенный меч обращающийся, чтобы охранить путь к дереву жизни" (Книга Бытия 3, 22, 24). На одним из изразцов над Древом Жизни расположены херувимы (рис. 5: 1). В Новом Завете написано, как Бог восстанавливает человеку доступ к Дереву. Древо Жизни это духовное древо познания добра через исполнение воли и права Божьего, вечной заповеди любви (Словарь 1974, 404-5). Христос обещает любому человеку, которой будет преданным Ему, потреблять плоды Древа Жизни, расположенного в Рае Бога (Апокалипсис 2,7; Словарь 1974, 404-405). При изображении небесного рая, мы видели колосья или цветы, к которым прилетают души, не исключительно только в виде голубей, но вообще в виде птиц (Уваров 1908, 156). Обобщение первоначального символа души, голубя, по всем вероятиям произошло под влиянием псалма 123: „Душа наша избавилась, как птица, из сети ловящих” (Псалтир 123, 7; Уваров 1908, 156). Птицы первоначально встречаются в связи с понятием о царствии небесном и этим самым с догматом Воскресения (Уваров 1908, 156). 

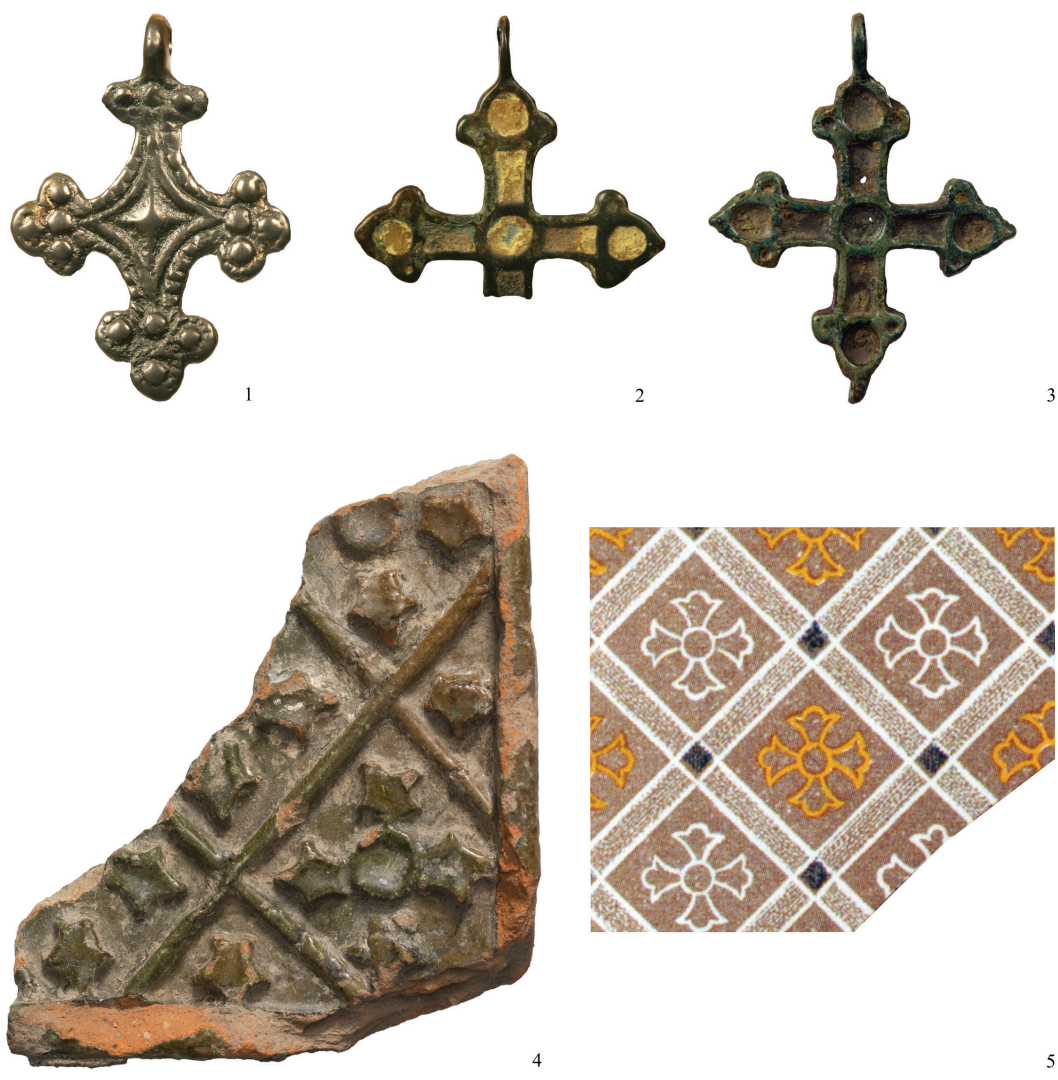

Рис. 4. 1-2. Данилово Малое, Подляшское воеводство. Древнерусские нательные крестики из 12. - первой половины 13. веков, найдены в раннесредневековых могилах. 3. Свенцк-Струмяны, Подляшское воеводство. Древнерусский нательный крестик из 12. - первой половины 13. веков, найдены в раннесредневековей могиле. 4. Дрогичин, изразец из второй половины 16. века.

Размер - высота: 99 мм; ширина: 95 мм; глубина: 46 мм. 5. Рим, церква СанЛоренцо-фуори-ле-Мура. Мотив креста в ромбоидальной сетке на покрывалах гробниц (Лоренц 1898, таблица 34)

Сл. 4. 1-2. Данилово Мало, Подласко војводство. Стари руски напрсни крстови из 12. и прве половине 13. века, пронађени у раносредњовековним гробовима.

3. Свјецк-Струмани, Подласко војводство. Староруски напрсни крст из 12. и прве половине 13. века, пронађен у раносредњовековној гробници. 4. Дрогичин, плочица из друге половине 16. века. Димензије - висина: 99 мм; ширина: 95 мм; дубина: 46 мм. 5. Рим, црква Сан Лоренцо фуори ле мура. Мотив крста у ромбоидној мрежи на покривачима гробова (Лоренц 1898, табела 34) 

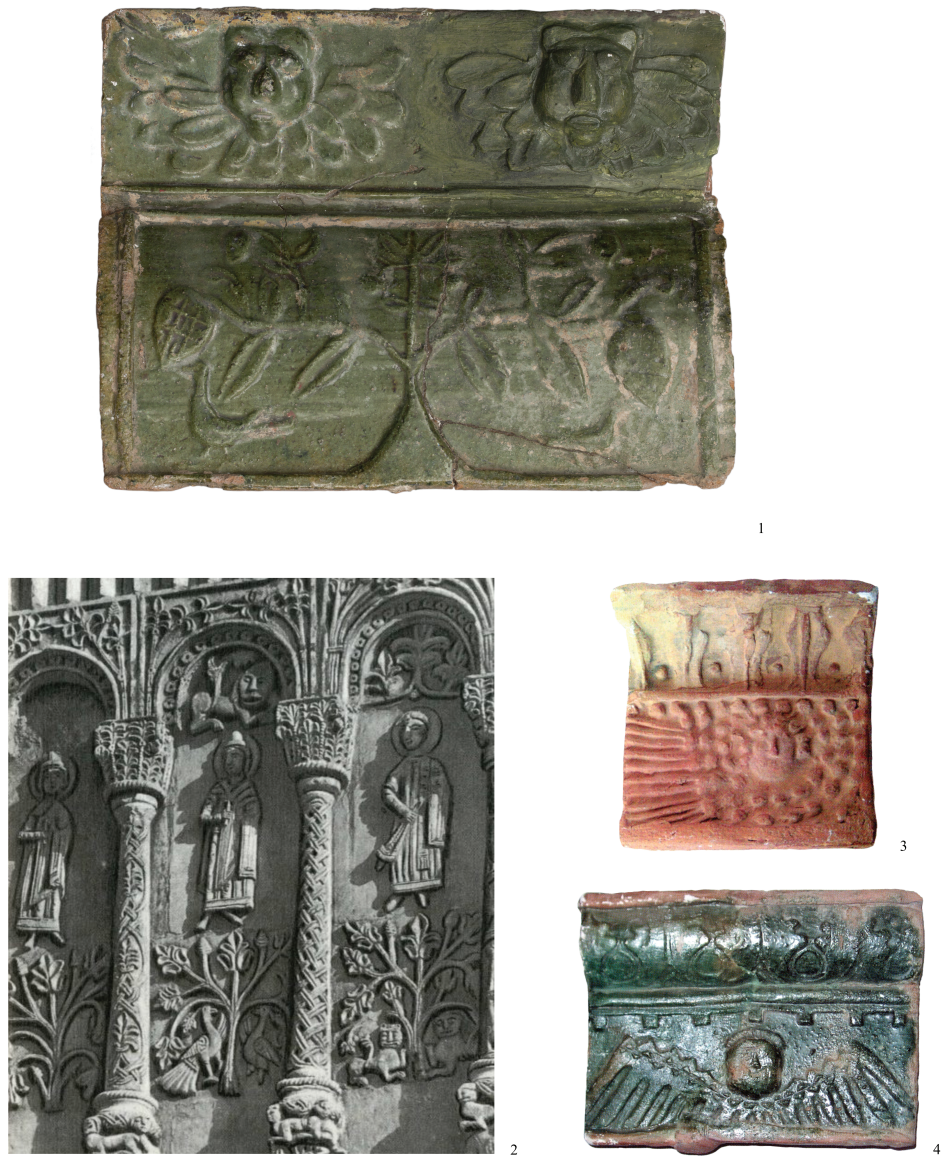

Рис. 5. 1. Супрасьль, изразец из второй половины 16. века. Размер - высота: 154 мм; ширина: 199 мм; глубина: 84, 107 мм. 2. Владимир, Россия. Собор Святого Великомученика Димитрия Солунского. Рельефы центрального прясла западного фасада, 90. года 12. века. Храмовая архитектура Древней Руси. (https://www. арублев.pф/read-02-006-02, доступ: 18. 03. 2021). 3. Крево, Беларусь, изразец из первой половины 16. века (Dziedzictwo Archeologiczne Podlasia i Grodzieńszczyzny 2007, 55). 4. Мир, Беларусь, изразец из конца 16. - первой половины 17. веков (Dziedzictwo Archeologiczne Podlasia i Grodzieńszczyzny 2007, 59)

Сл. 5. 1. Супрасл, плочица из друге половине 16. века. Димензије - висина: 154 мм; ширина: 199 мм; дубина: 84, 107 мм. 2. Владимир, Русија. Храм Светог великомученика Димитрија Солунског. Рељефи централног дела западне фасаде, 90. године 12. век. Храмовна архитектура древне Русије. (https://www.арублев. pф/read-02-006-02, приступљено: 18. 03. 2021). 3. Крево, Белорусија, плочица из прве половине 16. века (Dziedzictwo Archeologiczne Podlasia i Grodzieńszczyzny 2007, 55). 4. Мир, Белорусија, плочица с краја 16. и из прве половине 17. века

(Dziedzictwo Archeologiczne Podlasia i Grodzieńszczyzny 2007, 59) 

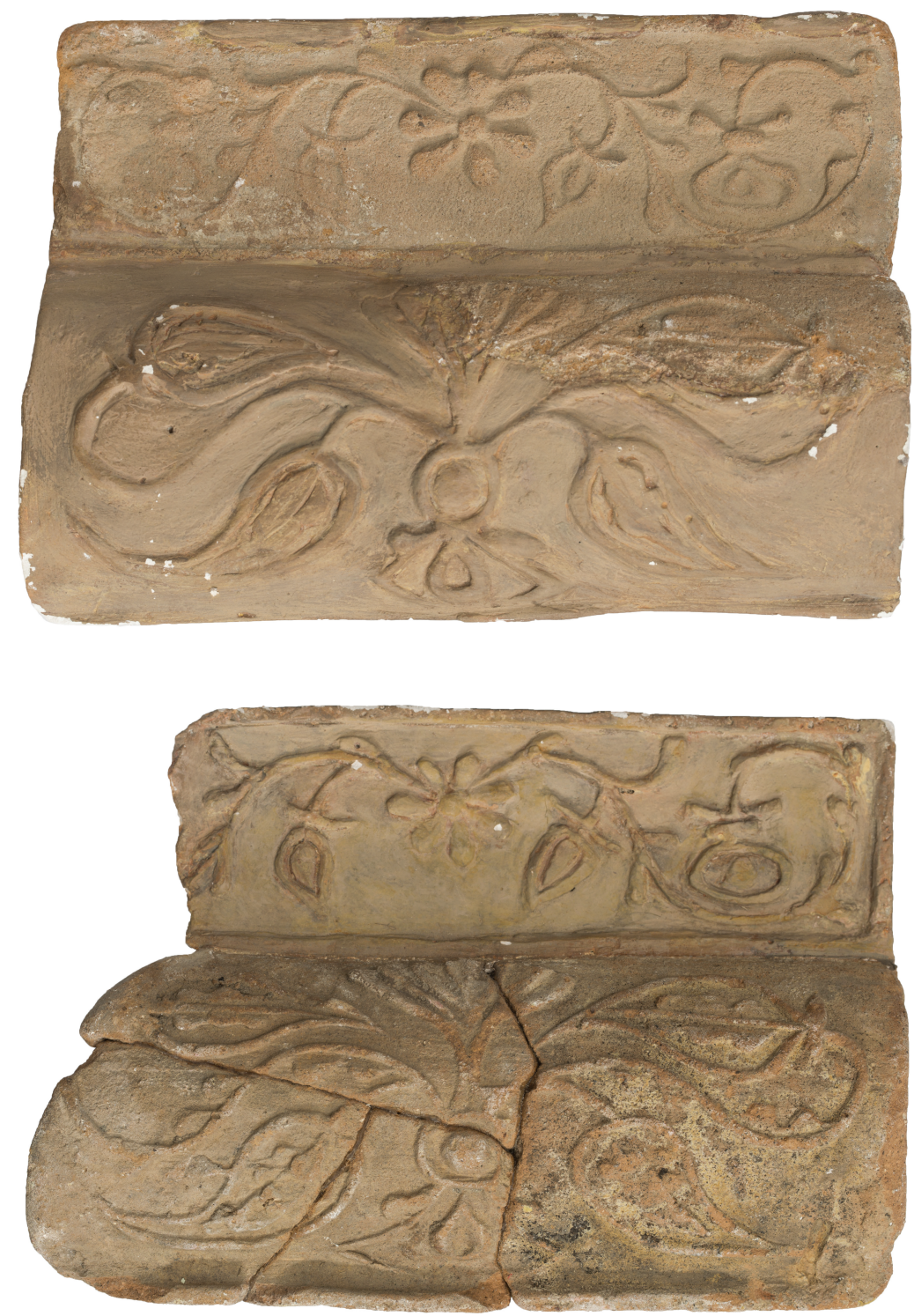

Рис. 6. Супрасьль, изразцы из второй половины 16. века - начала 17. века. 1. Размер - высота: 136 мм; ширина: 191 мм; глубина: 85 мм. 2. Размер - высота: 132 мм; ширина: 189 мм

Сл. 6. Супрасл, плочице из друге половине 16. века и почетка 17. века. 1. Димензије - висина: 136 мм; ширина: 191 мм; дубина: 85 мм.

2. Димензије - висина: 132 мм; ширина: 189 мм 

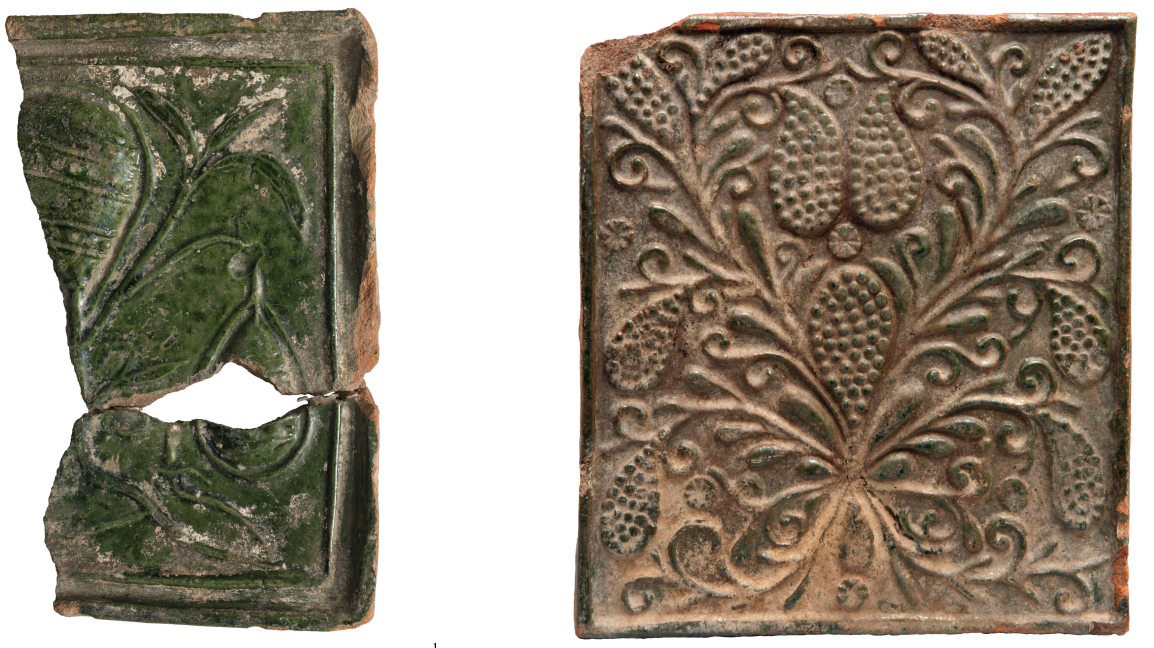

Рис. 7. 1. Дрогичин, изразец из второй половины 16. века. Размер - высота: 154 мм; ширина: 199 мм; глубина: 84, 107 мм. 2. Дубно около Бельска, изразец из 17. века (Garas, Karwowska 2013, 219, рис. 7)

Сл. 7. 1. Дрогичин, плочица из друге половине 16. века. Димензије - висина: 154 мм; ширина: 199 мм; дубина: 84, 107 мм. 2. Дубно близу Белска, плочица из 17. века (Garas, Karwowska 2013, 219, сл. 7)

Мотив Древа Жизни был изображён на изразцах найденных в Дрогичыне и Супрасьле (рис. 6, 7: 1). В византийском исскустве такого типа символические представления с X-XI веков украшают сегодня иконостас в соборе Успения Девы Марии, на острове Торчелло в Венецианской лагуне, Италья. Похожий мотив Древа Жизни и павлин находится на иллюминированной русской рукописи в книге Патерик Римский, датированным на конец XIV? - начало XV века, расположенный в Супраской библиотеке в XVI веке (Mironowicz 2014, 104). Эта изобразительная и знаковая символика Древа Жизнии и птиц есть известна в сербской архитектуре Средневековья. Примером является северный портал собора Спаса Вседержителя в монастыре в Высоких Дечанах, Сербия (Serbian Artistic Heritage 2017, 8, 12). Аналогическе представление херувимов находится на изразцах с Крэвы (Dziedzictwo archeologiczne Podlasia i Grodzieńszczyzny 2006, 55) и Иказни, Беларусь (Заяц 2001, 452, мал. 226: 4).

Наиболее важным христианским символом является крест. Одним из наиболее старых его изображений есть крест греческий, символизирующий Христа. Симеон Солунский так писал о значении этого символа: 

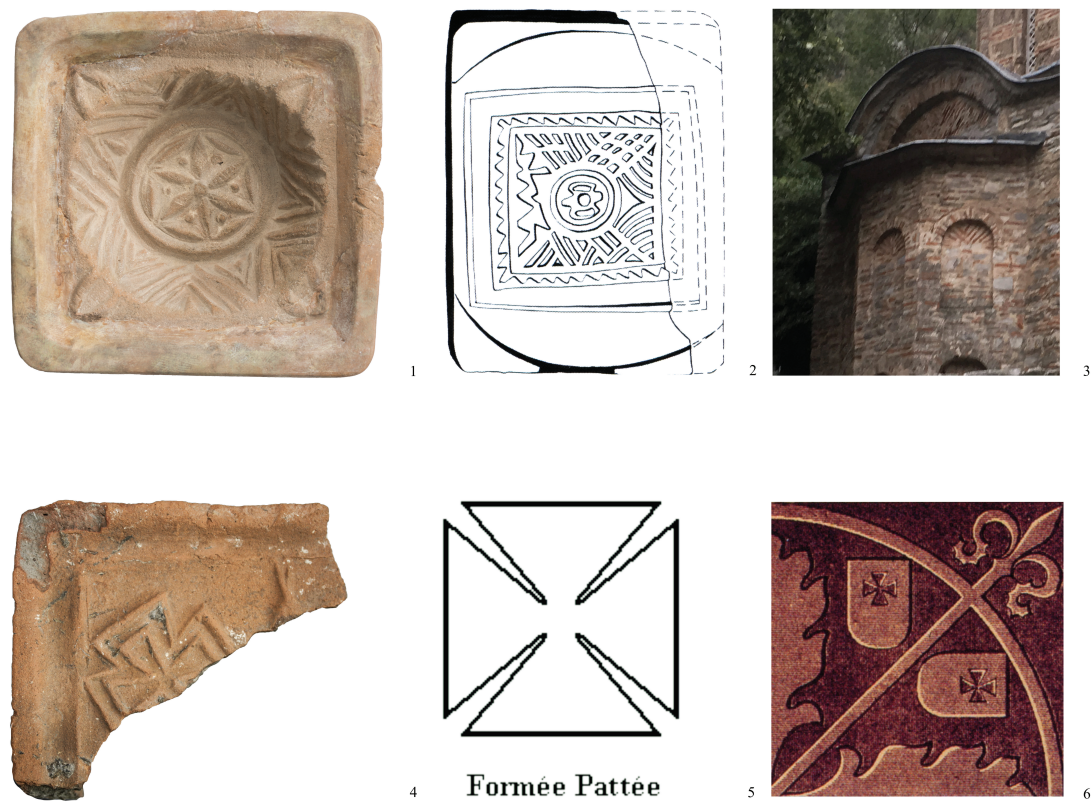

Рис. 8. 1. Тыкоцин, изразец из первой половины 16. века. Размер - высота: 179 мм; ширина: 180 мм, глубина: 57 мм. 2. Витебск, Беларусь, панно (?), 16. век (Бубенько 2007, 255, рис. 2: 5). 3. Матка (канион), Северная Македония, монастырь святого

Андрея. 4. Тыкоцин, монастырь бернардинцев, изразец из 16. века. Размер высота: 91 мм; ширина: 110 мм; глубина: 49 мм. 5. Лапчатый крест (http://www.lishfd.org/History/history_of_the_maltese cross.htm., доступ: 18. 03. 2021)

6. Гайльдорф, Германия, изразец из 14. века (Лоренц 1898, таблица 43)

Сл. 8. 1. Тикоћин, плочица из прве половине 16. века. Димензије - висина: 179 мм; ширина: 180 мм, дубина: 57 мм. 2. Витебск, Белорусија, пано (?), 16. век (Бубенько 2007, 255, сл. 2: 5). 3. Матка (кањон), Северна Македонија, Манастир Светог Андреја. 4. Тикоћин, бернардински манастир, плочица из 16. века. Димензије висина: 91 мм; ширина: 110 мм; дубина: 49 мм. 5. Темпларски крст (http://www.lishfd.org/History/history_of_the_maltese cross.htm., приступљено 18. 03. 2021) 6. Гајлдорф, Немачка, плочица из 14. века (Лоренц 1898, табела 43)

„К востоку за престолом ставится четвероконечный Божественный крест Спасителя, на котором Он, грех ради наших, был пригвождён, - Спасителя, Который сотворил и содержит все горнее и дольнее, Который соединил горнее с земным, свыше исшел на землю, и потом с земли вознёсся на небо; в Себе Самом все соединил и к Себе призвал все концы земли. Который высотою Божества и смирением воплощения все Себе усвоил и воссоздал нас высотою славы, глубиною нищеты и смирения, и широтою милости и любви, и за нас воздвигнул и из земных сделал небесными" (Вениамин 1999, 16-17). 
Вот что образует крест. Эта форма креста распространена в сакральном искусстве на территориях прежней Византийской Империи (рис. 4: 5), Сербии и Руси. Очень часто крест расположен внутри растительного орнамента. Одними из примеров являются иллюминированные сербские средневековые рукописи (Serbian Artistic Heritage 2017, 410-411). Аналогический мотив креста в ромбоидальной сетке украшает покрывала гробниц церкви Сан-Лоренцо-фуори-ле-Мура в Риме (Лоренц 1898, таблица 34). Прямыми аналогиями являются нательные кресты из бронзы коричневого цвета и с выемчатыми эмалями эпохи раннего Средневековья (рис. 4: 1-3), найденые на территории древней Руси (между прочем на могилах в Данилове Малым, гмина Лапы, Подляшское воеводства). Мотив креста находился под стилизованными ветвями Древа Жизни (изразец из Дрогичына, рис. 3: 1) или в ромбоидальной сетке (изразец из Дрогичына, рис. 4: 4, изразец из Дубна, Подляшье (Garas, Karwowska 2013, рис. 3: 2)). Похожий мотив креста изображён под Древом Жизни на изразце найденным в Полоцке (Дук 2012, рис. 80: 1).

Интересным религиозным сюжетом, украшающим изразец из города Тыкоцина, является шестилепестковая, вписанная в круг розетка, званная «Цветком Жизни», широко распространена на территории Славянщины, Греции, Центральной Азии, Ближнем Востоке и Западной Европе. В языческих верованиях исполняла роль магическо- защитную. В христианской символике обозначала свет воскресшего Христа - Утренней Звезды. Звезду устраивали в сакральной архитектуре, в раннехристианском периоде, старых христианских храмах (полы, устои, фасады, мраморные доски) на территории Восточной Римской Империи, в церкви Святой Софии в Константинополе (Koch 2013, 40), в Филлиппи (современное Кринидэс, Греция), и прочие, и в прикладном искусстве, на пример на лицевых пластинах изразцов, найденных в Бэндземысьлю, Польша (Czopek 1994, 102-103), Вильнюсе, Литва (Rackevicius 2012, 82, 247-8), Вад, Румыния (Marcu 1994, 164, рис. 5), Быстрицы, Словакия (Macelova 2005, 216, рис. 4: 2), хотя в другой ренессансной и готической стилистике. Конструкция Тыкоцинского изразца припоминает „medallion tiles”, найдены в Люнд (Швеция), датированы исследователями на XVI век (Sørensen 2017, 38, рис. 12). На пластине Тыкоцинского изразца Цветок Жизни находится в круглой нише, может быть имитирующей окно, окружённой и украшенной мотивом opus spicatum (рис. 8: 1), уложенный из кирпичей, напоминающий средневековые византийско-сербские сакральные, строительные традиции. Аналогией является панно(?) с XVI века, с замка в Витебске, Беларусь (Бубенько 2007, 255, рис. 2: 5), изразцы из княжеской резиденции в Вильнусе (Lietuovos didžiujų kunigaikščiu 
rezidencija Vilniuje 2010, 128), и с Пидгородия, Потелича, и Старого Збаража, Украина (Івашкив 2005, 153, рис. 6). Мотив шестилепестковой, вписанной в круг розетки расписан на записи находящейся на стене Николаевской церкви Морачаского монастыра, Сербия (Манастир Морача 2011, 52-53), южным портале собора Спаса Вседержителя монастыра в Высоких Дечанах, документе уставе монастыря в Высоких Дечанах, Сербия (Serbian Artistic Heritage 2017, 6, 360-361, 366-367), украшает русскую иконную ризу с XVII столетия, находящуюся в XIX веке в музее Императорского Общества Пошерения Художеств в Петербурге (Лоренц 1898, табл. 37: 18).

На особое внимание заслуживает изразец со святым Георгием (рис. 9: 3). На территории Восточной и Центральной Европы в Средневековье очень популярными были представления священных мучеников, особенно святого Георгия на лошади убивающего змея. Святой Георгий - усмиритель змеев возникает в искусстве Византии в XII столетии, на Востоке и в Италии, откуда распространяется на Западную Европу (Gruia $2006,9)$. На Востоке, во византийско-русской цивилизации, Святой представляется с нимбом, сплошь и рядом знакомленный, в римской арматуре и хламиде, стоящий или убивающий змея с оконченным крестом копьём, коронованный ангелами или благословленный Божью Рукой (Gruia 2006, 9). В западным (латинским) искусстве Святой Георгий представляется как мученик на пытках или как рыцарь в современной арматуре, убивающий змея копьём или мечом, в присутствии принцессы (Gruia 2006, 9). На фрагменте изразца из Дрогичина изображён святой Георгий с нимбом, на лошади, благословленный Божью Рукой, во византийско-русской стилистике. Аналогические представления Святого Георгия убивающего змея написаны на русских иконах XV-XVI веков (Бузыкина, Трубицын 2013, рис. 1-2) и изображённые в камне с XIV века (Лупиненко 2010, рис. 15). В сербском сакральном искусстве XVII века святой Георгий Победоносец убивающий змея находится на фасаде церкви Святого Кириаки в Брнячи около Ораговача, Сербия (Serbian Artistic Heritage 2017, 342-343).

Примером готического исскуства о религиозной тематике является изразец с лапчатым крестом (лат. pattée formée, рис. 8: 5) из XVI столетия (рис. 8: 4), найденный на территории монастыря бернардинцев в Тыкоцине, заложенного в 1479 году. Этот прямой равносторонний крест с расширяющимися концами (рис. 8: 6) выводится од иоаннитов - Ордена братьев иерусалимского госпиталя святого Иоанна Крестителя (лат. Fratres Hospitalis sancti Ioannis Hierosolymitani), званных от мест деятельности Родосскими, а после Мальтийскими рыцарями (Foster 2004, data dostępu: 22.02.2021 r., 

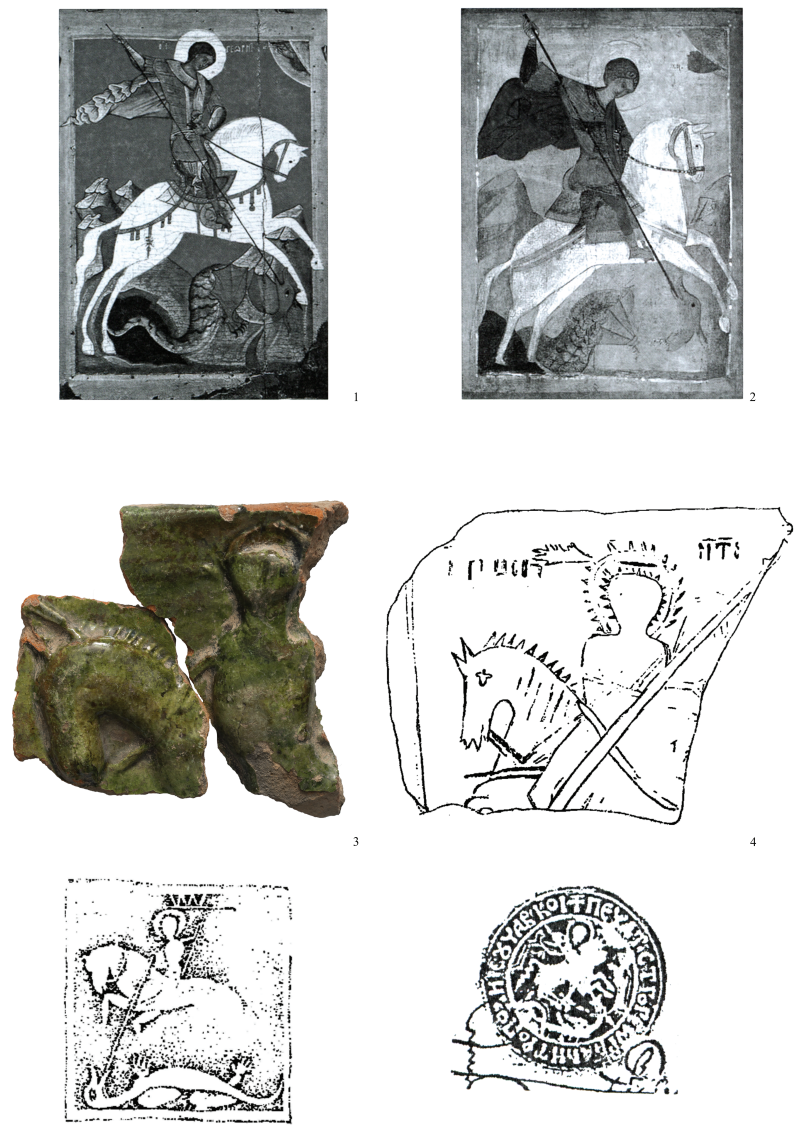

Рис. 9. 1. Манихино на реке Паше, Россия. Чудо Светого Георгия о змие. 15. век (Бызыкина, Трубицын 2013, рис. 1). 2. Нёмруша на реке Онеге, Россия. Чудо Светого Георгия о змие. Рубеж 15. и 16. веков (Бызыкина, Трубицын 2013, рис. 2).

3. Дрогичин, изразец из 16. века. Размер - высота: 56 мм, 92 мм; ширина: 59 мм, 51 мм; глубина: 34 мм. 4. Тырговиште, жудец Дымбовица, Румыния, изразец из 16. века (Gruia 2006, 41, W4). 5. Сучава, жудец Сучава, Румыния, изразец (Gruia 2006, 39, M19). 6. Печать метрополии Молдавского княжества (Беженару і Бакуменко 2003-2004, 434, рис. 3: 5a)

Сл. 9. 1. Манихино на реци Паши, Русија. Свети Ђорђе убија аждају, 15. век (Бызыкина, Трубицын 2013, сл. 1). 2. Њомруша на реци Оњега, Русија. Свети

Ђорђе убија аждају. На прелазу из 15. у 16. век (Бызыкина, Трубицын 2013, сл. 2).

3. Дрогичин, плочица из 16. века. Димензије - висина: 56 мм, 92 мм; ширина:

59 мм, 51 мм; дубина: 34 мм. 4. Трговиште, округ Дамбовица, Румунија, плочица из 16. века (Gruia 2006, 41, W4). 5. Сучава, округ Сучава, Румунија, плочица (Gruia 2006, 39, M19). 6. Печат метрополе молдавске кнежевине (Беженару i Бакуменко 2003-2004, 434, сл. 3: 5а) 
http://www.lishfd.org/History/history_of_the_maltese_cross.htm). Неполное coстояние сохранения предмета не позволяет определить контекст, в каким он выступил на изразце, а также какая была его связь с Тыкоцинскими бернардинцами или донаторами этого монастыря.

\section{Изразцы с архитектоническими сюжетами}

Архитектонические мотивы изразцов собранных в музее изображают стилистику, геометрию и мотивы готической архитектуры. На лицевых пластинах наблюдается стилизованные вращенные розетки (рис. 10: 3) из Дрогичина (аналогия изразец из Вильна, тип I/26 за: Rackevicius 2012, 264) и восьмилепестковую розетку из замка в Мельнике (рис. 10: 1). Мотивы розеток и масверков напоминают витражи готических окон (Macelova 2005, 210). Розетки украшают лица изразцов вавельских, краковских (Moskal 2012, 35, 118-127), минских (Заяц 2001, 452, мал. 220: 2), виленских (Striškienè 2007, рис. 22; Lietuovos didžiujų kunigaikščių rezidencija 2010, 128), мальборских (Pospieszna 2013, 83-4), люблинских (Niedźwiadek 2007, 90-1) (рис. 10: 4) и бэндземыльских (Czopek 1994, 107).

Другими интересными сюжетами позднеготической архитектуры являются помещены на изразцах из замка в Мельнике пламенной масверк (рис. 11: 2) (аналогия изразец из Запсано, Brych 2004, 137, рис. 317), позднеготический крестоцвет на коронке для оформления верха печи (рис. 10: 2), и найдены в городе Тыкоцин стилизованной пинакль (рис. 11: 1). Интересным примером изразца из монастыря бернардинцев в Тыкоцине является изразец с позднеготической архитектурой в виде схематического представления масверка и травеи (рис. 11: 4).

Очень интересный архитектурный сюжет представляют изразцы из замка в Мельнике. На них изображены ворота позднеготического замка с тремя башнями, с бифорием перекрытым аркой, и с двумя защитниками между ними (рис. 12: 1, 3, 4). Нельзя исключить, что образцом для изображения на этих изразцах был Мельницкий замок, от какого сохранились развалы, между прочем Римско-католической церкви, которая была элементом оборонного комплекса. Аналогический изразец, но представляющий герб Нового Места (рис. 12: 2), находится в коллекции Народного Музея в Праге (Чехия) (Brych 2004, 48-9, рис. 46-50).

\section{Изразцы с геральдическими сюжетами}

Простой и разборчивый знак, каким является герб, служил к скорой идентификации потомственной принадлежности и как символ 

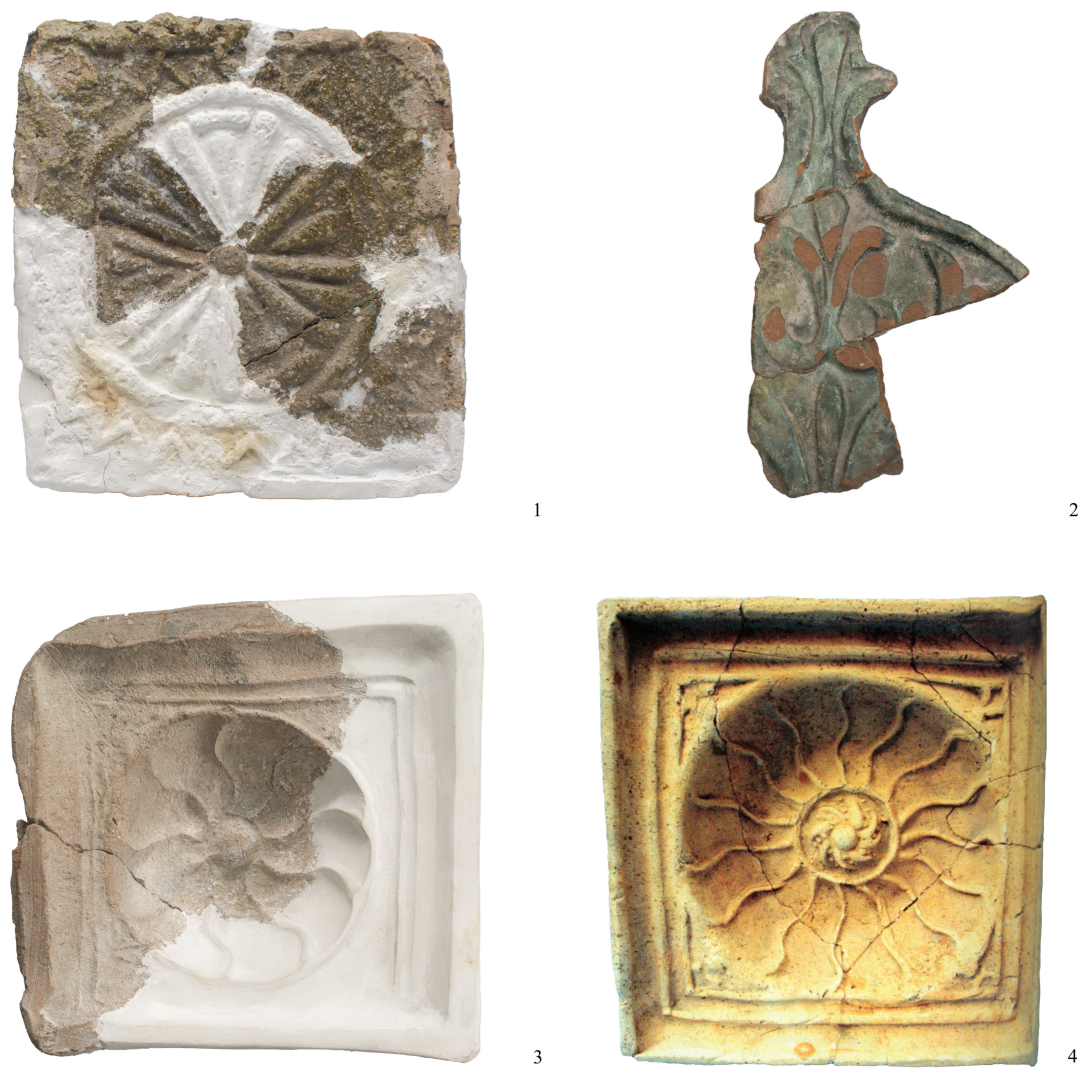

Рис. 10. 1. Мельник, изразец из первой половины 16. века. Размер - высота: 175 мм; ширина: 168 мм; глубина: 102 мм. 2. Мельник, изразец из второй половины 16. века. Размер - высота: 162 мм; ширина: 93 мм; глубина: 24 мм. 3. Дрогичин, изразец из первой половины 16. века. Размер - высота: 144 мм; ширина: 157 мм; глубина: 43 мм.

4. Люблин, Польша, изразец из 16. века (Niedźwiadek 2007, 90, рис. 6b)

Сл. 10. 1. Мјелњик, плочица из прве половине 16. века. Димензије - висина: 175 мм; ширина: 168 мм; дубина: 102 мм. 2. Мјелњик, плочица из друге половине 16. века. Димензије - висина: 162 мм; ширина: 93 мм; дубина: 24 мм. 3. Дрогичин, плочица из прве половине 16. века. Димензије - висина: 144 мм; ширина: 157 мм; дубина: 43 мм.

4. Лублин, Пољска, плочица из 16. века (Niedźwiadek 2007, 90, сл. 6b)

дворянского достоинства быстро мигрировал по средневековым полям боя к миру изящных и утилитарных искусств, между прочим к ремеслу печника (Znamierowski 2003, 29).

В Сураже был найденный изразец с гербом Пелеш - два скрещённые мечи с направленными к верху остриями, между которыми расположен лапчатый крест, по сторонам две шишки (рис. 15: 1). Над щитом 

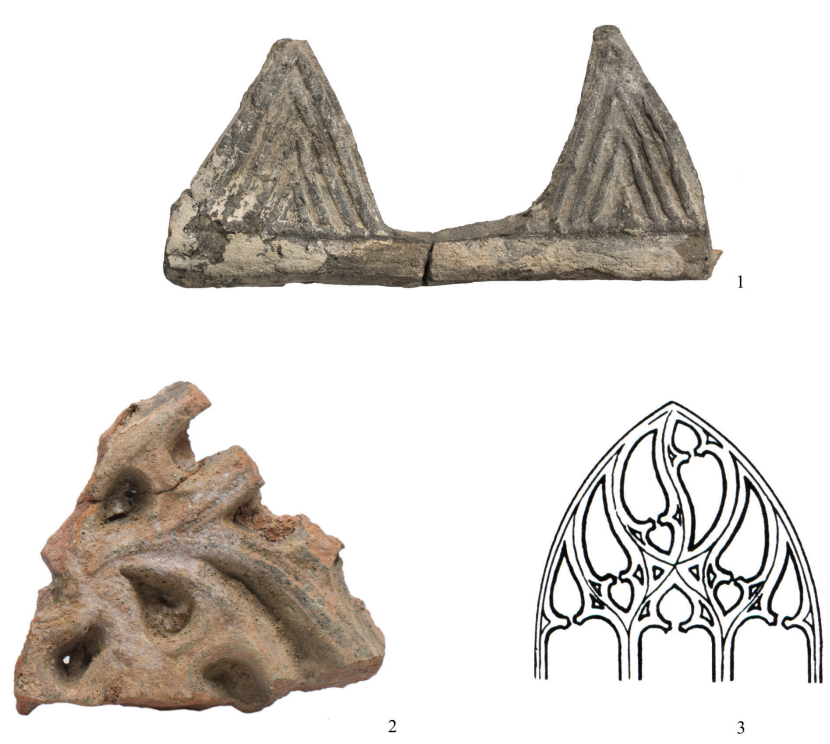

3
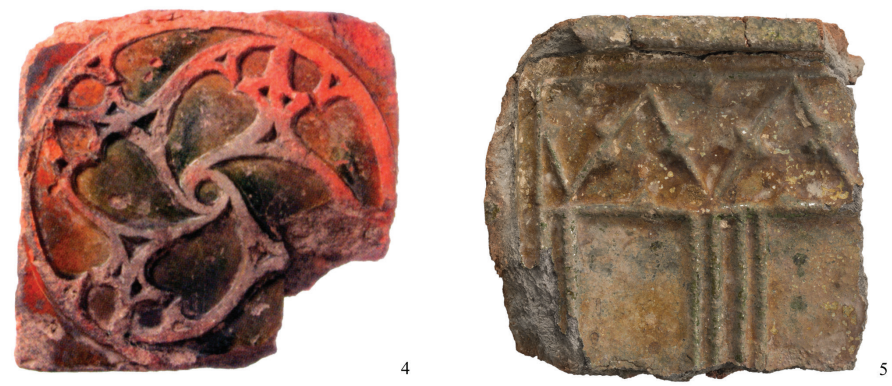

Рис. 11. 1. Тыкоцин, изразец из 16. века. Размер - высота: 84 мм; ширина: 178 мм. 2. Мельник, изразец из первой половины 16. века. Размер - высота: 70 мм; ширина: 66 мм. 3. Позднеготической пламенной масверк (Koch 2009, 163). 4. Вильно. Керамическая плитка, 15. век (Striškienè 2007, рис. 22: 1). 5. Тыкоцин, монастырь бернардинцев, изразец из конца 15. века - первой половины 16. века. Размер - высота: 105 мм; ширина: 106 мм; глубина: 45 мм

Сл. 11. 1. Тикоћин, плочица из 16. века. Димензије - висина: 84 мм; ширина: 178 мм. 2. Мјелњик, плочица из прве половине 16. века. Димензије - висина: 70 мм; ширина: 66 мм. 3. Касноготски раскошни масверк (Koch 2009, 163). 4. Вилњус. Керамичке плочице, 15. век (Striškienè 2007, сл. 22: 1). 5. Тикоћин, бернардински манастир, плочица с краја 15. века и из прве половине 16. века. Димензије - висина: 105 мм; ширина: 106 мм; дубина: 45 мм 

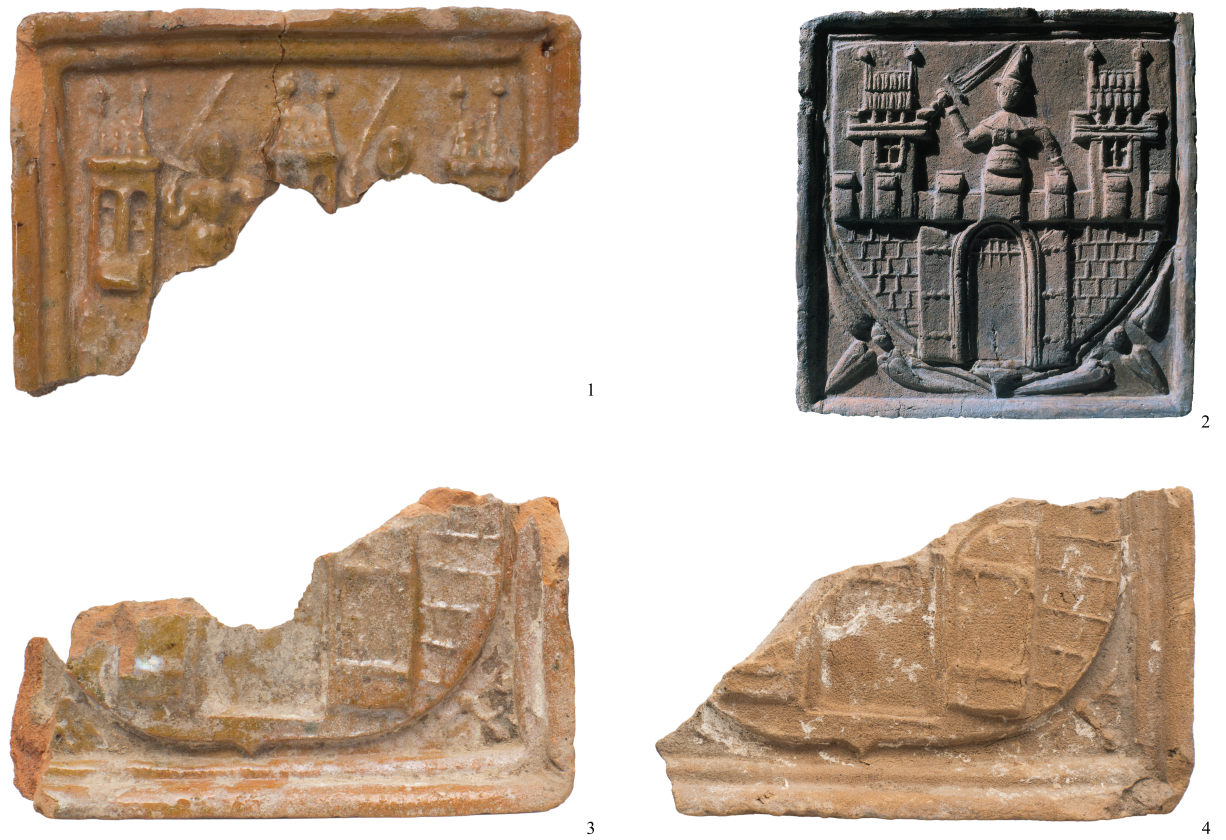

Рис. 12. 1, 3-4. Мельник, изразцы из второй половины 15. века - начала 16. века. Размер - 1: высота: 102 мм; ширина: 155 мм; глубина: 104 мм; 3: высота: 79 мм; ширина: 144 мм; глубина: 77 мм; 4: высота: 81 мм; ширина: 132 мм; глубина: 64 мм.

2. Прага, Чехия, изразец из 16. века (Brych 2004, 48, рис. 46)

Сл. 12. 1, 3-4. Мјелњик, плочице из друге половине 15. и почетка 16. века. Димензије - 1: висина: 102 мм; ширина: 155 мм; дубина: 104 мм; 3: висина: 79 мм; ширина: 144 мм; дубина: 77 мм; 4: висина: 81 мм; ширина: 132 мм; дубина: 64 мм.

2. Праг, Чешка, плочица из 16. века (Brych 2004, 48, сл. 46)

кириллицей: первый неразборчивый знак и две буквы И или Й, Щ. Некоторые авторы приписывали эту разновидность герба Пелеш о татарском или русско-литовском происхождении роде Йельских (Jelscy 2007, https:// amp.google-info.pl/3791440/1/jelscy-herbu-pielesz.html; доступ: 18.03.2021 г.). Около 1520 года родился родоначальник семьи Константин, который имел два сына Гавриила и Щенсного (Jelscy 2007). Вероятно, что этот герб и инициалы принадлежали второму сыну.

Интересным примером гербового изразца, найденного на улице Броварной в Тыкоцине, является изображение двуглавого орла (рис. 15: 3) (Niziołek i Taranta 2020, 176). Двуглавый орёл был гербом Восточной Римской империи со времён господства династии Палеологов и обращающейся к его традиции Руси (рис. 15: 2), Православной церкви, Римской империи Германской нации и некоторых Германских городов (между прочем Любеки). 

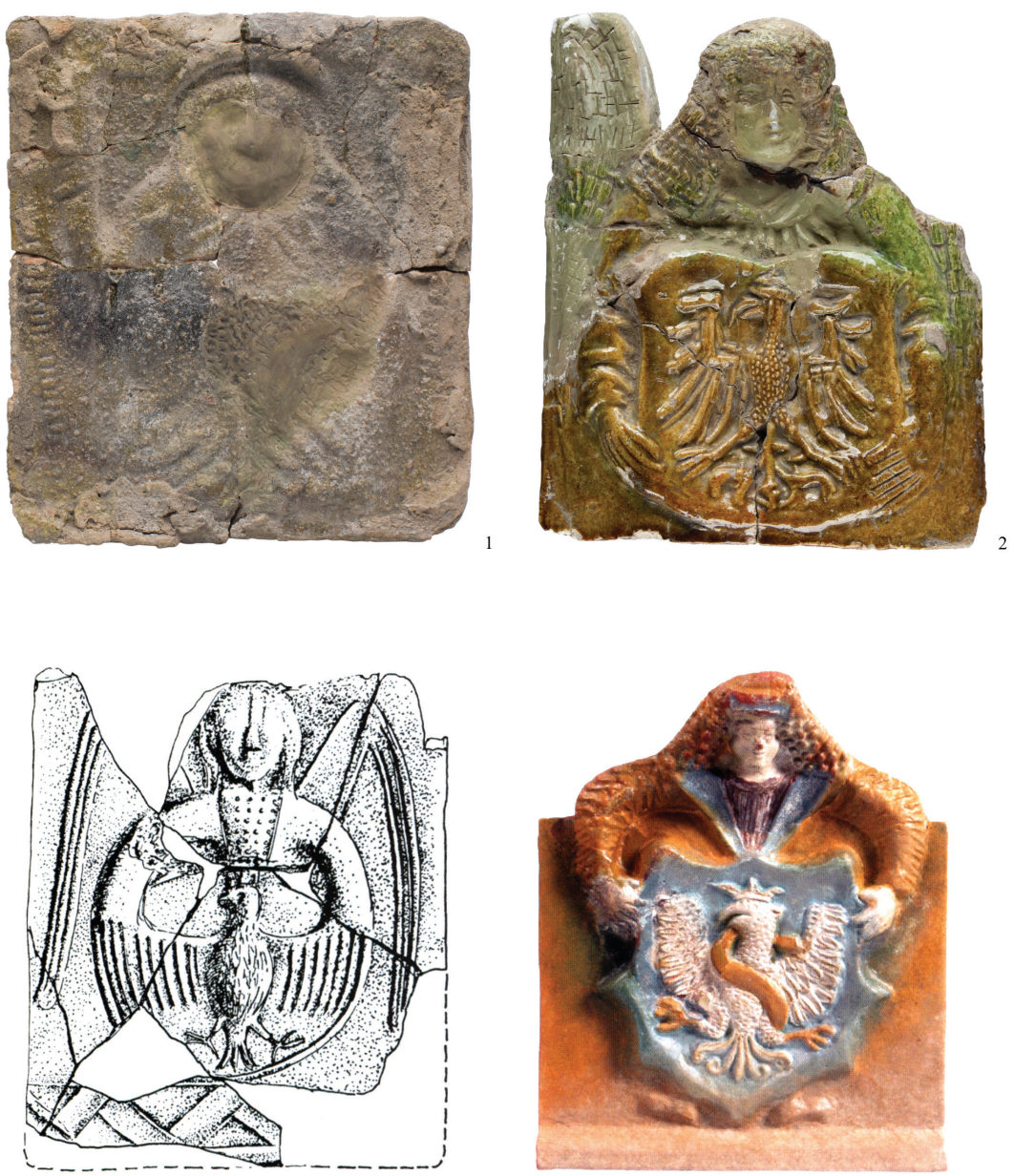

3

Рис. 13. 1. Мельник, изразец из половины 16. века. Размер - высота: 201 мм; ширина: 176 мм; глубина: 101 мм. 2. Пиньчув, Польша, изразец из Национального музея в Кельцах (https://mnki.pl/pl/o_muzeum/zbiory_online/5,archeologia/ pokaz/296,kafel_z_aniolem_tarczownikiem,2\#lg=1\&slide=0; доступ: 18. 03. 2021). 3. Львов - Арсенал, Украина, изразец из 16. века (Гупало, Лосик 2005, рис. 9: 2).

4. Вильно, изразец из второй третьи 16. века (Lietuovos didžiujų kunigaikščiu rezidencija Vilniuje 2010, рис. 305)

Сл. 13. 1. Мјелњик, плочица из средине 16. века. Димензије - висина: 201 мм; ширина: 176 мм; дубина: 101 мм. 2. Пињчов, Пољска, плочица из Народног музеја у Кјелцу (https://mnki.pl/pl/o_muzeum/zbiory_online/5,archeologia/pokaz/296,kafel_z_ aniolem_tarczownikiem,2\#lg=1\&slide=0; приступљено 18. 03. 2021).

3. Лавов-Арсенал, Украјина, плочица из 16. века (Гупало, Лосик 2005, сл. 9: 2).

4. Вилњус, плочица из друге трећине 16. века (Lietuovos didžiujų kunigaikščču rezidencija Vilniuje 2010, сл. 305) 

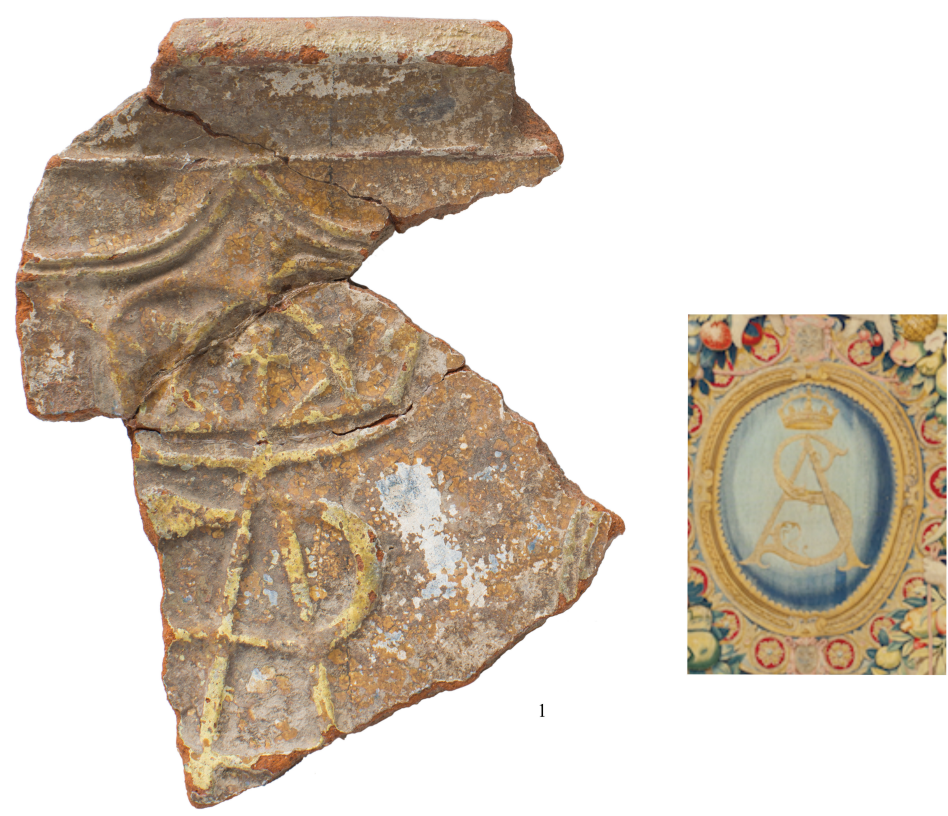

Рис. 14. 1. Мельник, изразец из третьей третьи 16. века. Размер - высота: 151 мм; ширина: 102 мм. 2. Краков, Вавельский замок, Польша. Фрагмент Арраса

Сигизмунда II Августа (www.wikipedia.org.pl; доступ: 18. 03. 2021)

Сл. 14. 1. Мјелњик, плочица из из треће трећине 16. века. Димензије - висина: 151 мм; ширина: 102 мм. 2. Краков, дворац Вавел, Пољска. Фрагмент Араса Сигисмунда II Августа (www.wikipedia.org.pl; приступљено 18. 03. 2021)

Двуглавый орёл Палеологов и Рюриковичей и подражаем им Православной церкви имеет характерно опущенные крылья, в отличие от орла семнадцатого века и очередных столетий, у которого крылья увлечённые вверх, по западноевропейской манере (Соболева 2006). Аналогичный печный изразец с орлом в округе но с опущенными крыльями - гербом Русской державы с первой третьи XVII века был найден в ходе исследований в Московском Кремле (Баранова 2016, рис. 6). Трудно приблизить причины демонстративного экспонирования императорского орла на коронке для оформления верха печи. Можно предполагать, что это была манифестация политических взглядов домовладельца, приверженца Габсбургов. В аспекте Инвентаря с 1571 года, в этой части города находился участок принадлежащий потомкам Троксого кастеляна - Георгия Александровича Ходкевича (AGAD, ASK LVI, t. 4, k. 16-17). Ходкевичи - элитарный русский род в Западной Руси православного вероисповедования, ктиторы православного монастыра в 

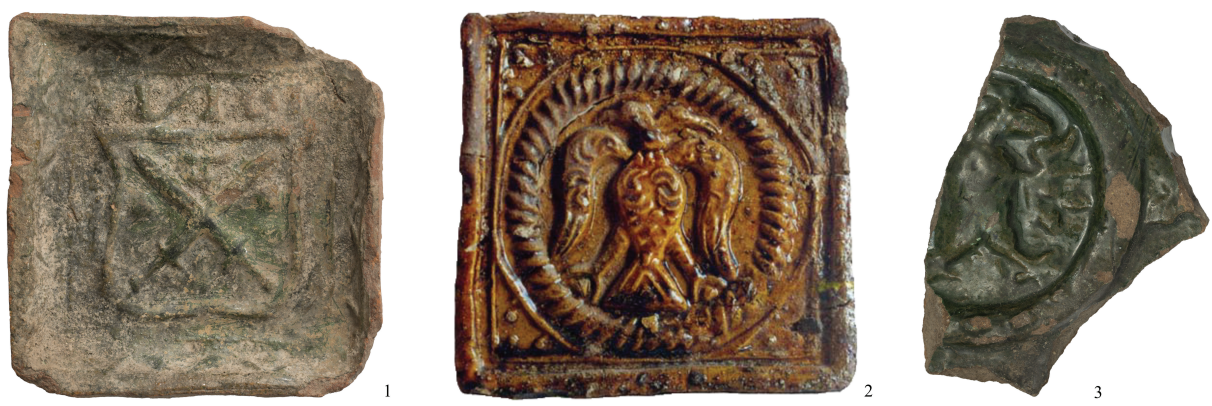

Рис. 15. 1. Сураж, изразец из 16. века. Размер - высота: 145 мм; ширина: 141 мм; глубина: 39 мм. 2. Москва, Кремль. Изразец из первой третьи 17. века (Баранова 2016, рис. 6). 3. Тыкоцин, изразцы из второй половины 16 . века.

Размер - высота: 119,5 мм; ширина: 84,5 мм

Сл. 15. 1. Сураж, плочица из 16. века. Димензије - висина: 145 мм; ширина: 141 мм; дубина: 39 мм. 2. Московски Кремљ. Плочица из прве трећине 17. века. 3. Тикоћин, плочице из друге половине 16. века. Димензије - висина: 119,5 мм; ширина: 84,5 мм

Супрасле $^{1}$ - были противниками унии Короны королевства Польского и Великого княжества Литовского и хотели избрания эрцгерцога Максимилиана Габсбурга князем Литвы по смерти Сигизмунда II Августа (DubasUrwanowicz 1995, 18).

На территории Мельницкого замка были найдены два изразцы с геральдическими мотивами: ангел или герольд держащий гербовый щит с Польским орлом (рис. 13: 1), вторично пережжённый, и декоративный вензель SA с перекрытую короной - Sigismundus Augustus (рис. 14: 1), последний Ягеллон на троне Речыпосполитой. Колорит орнамента (жёлтый), фоны (голубой) и вензеля (жёлтый) очень похож на композицию на аррасах в Вавельским замке в Кракове. Аналогический изразец с вензелем был найден в Виленским замке (Lietuovos didžiųų kunigaikščių rezidencija Vilniuje 2010, 206; Rackevicius 2012, 98, 447), а с ангелом в Бэндземысле (Czopek 1994, 101), Львове - Арсенале, Украина (Івашкив 2005, рис. 9).

\footnotetext{
${ }^{1}$ Основателем монастыра в Супрасле, который стал в XVI веке значимым центром не только религиозным но русской культуры, искусства и письменности, был Александр Иванович Ходкевич - отец Григория, Геронима и Георгия (Mironowicz 2017, 154, 156, 158). О происхождении этого рода писал иезуита Каспер Несецкий: древний дом на Литве, который принял название Ходко (Stupnicki 1855, 83). Он перемолчал особу Александра. Его внимание привлекают сыны Александра, Григорий и Героним, графы Римской Империи Германского Народа и их потомки новообращённые исповедовали католицизма (Stupnicki 1855, 83-85).
} 

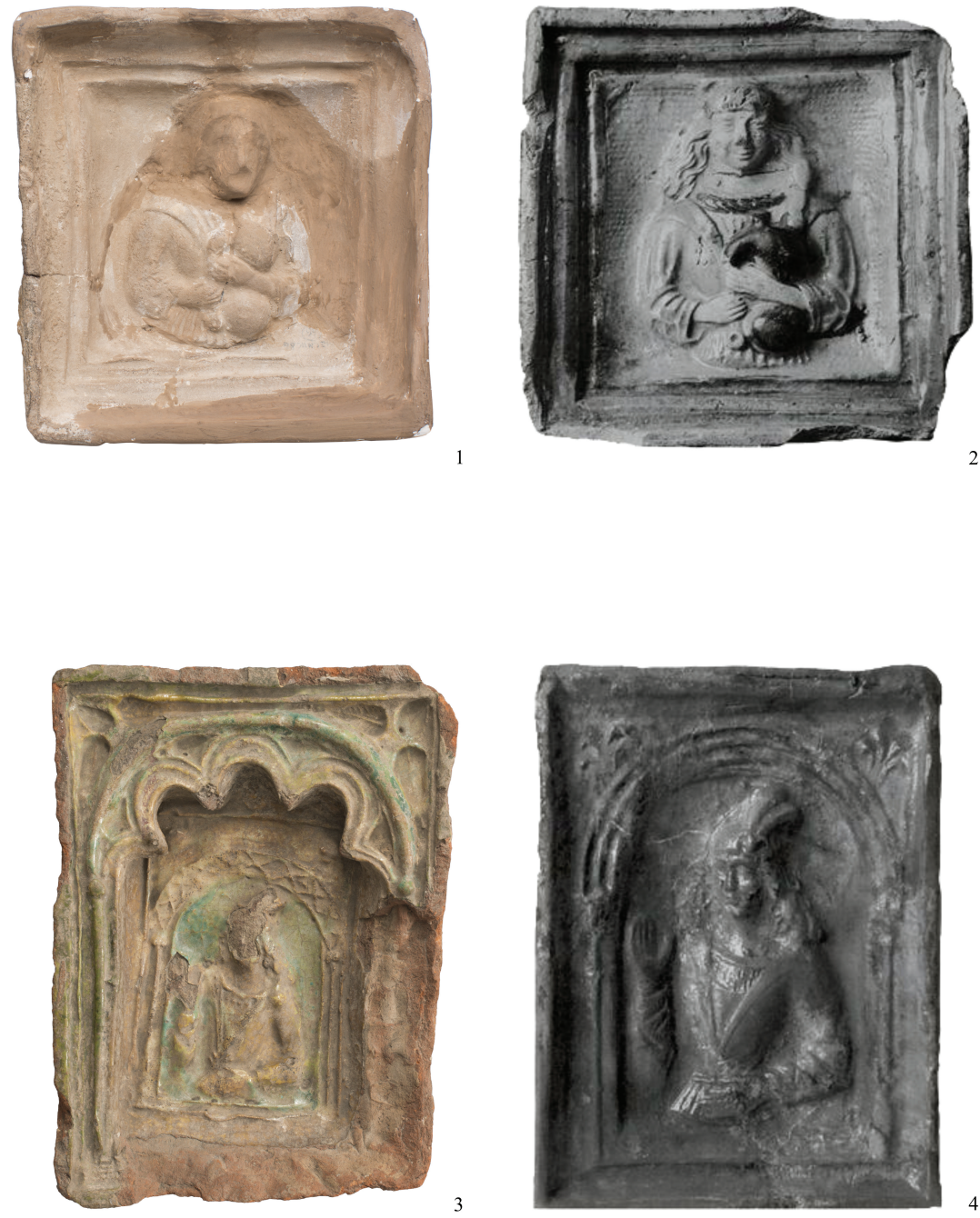

Рис. 16. 1. Мельник, изразец из половины 16. века. Размер - высота: 174 мм; ширина: 168 мм; глубина: 94 мм. 2. Болеславец над Просной, изразец из половины 16. века (Żemigała 1987, рис. 98). 3. Сураж, изразец из половины 16. века. Размер - высота: 225 мм; ширина: 171 мм; глубина: 59 мм. 4. Худов, Польша, изразец из половины 16. века (Tarasiński 2010, рис. 7)

Сл. 16. 1. Мјелњик, плочица из средине 16. века. Димензије - висина: 174 мм; ширина: 168 мм; дубина: 94 мм. 2. Болеславјец над Просном, плочица из средине 16. века (Żemigała 1987, сл. 98). 3. Сураж, плочица из средине 16. века. Димензије - висина: 225 мм; ширина: 171 мм; дубина: 59 мм. 4. Худов, Пољска, плочица из половине 16. века (Tarasiński 2010, сл. 7) 

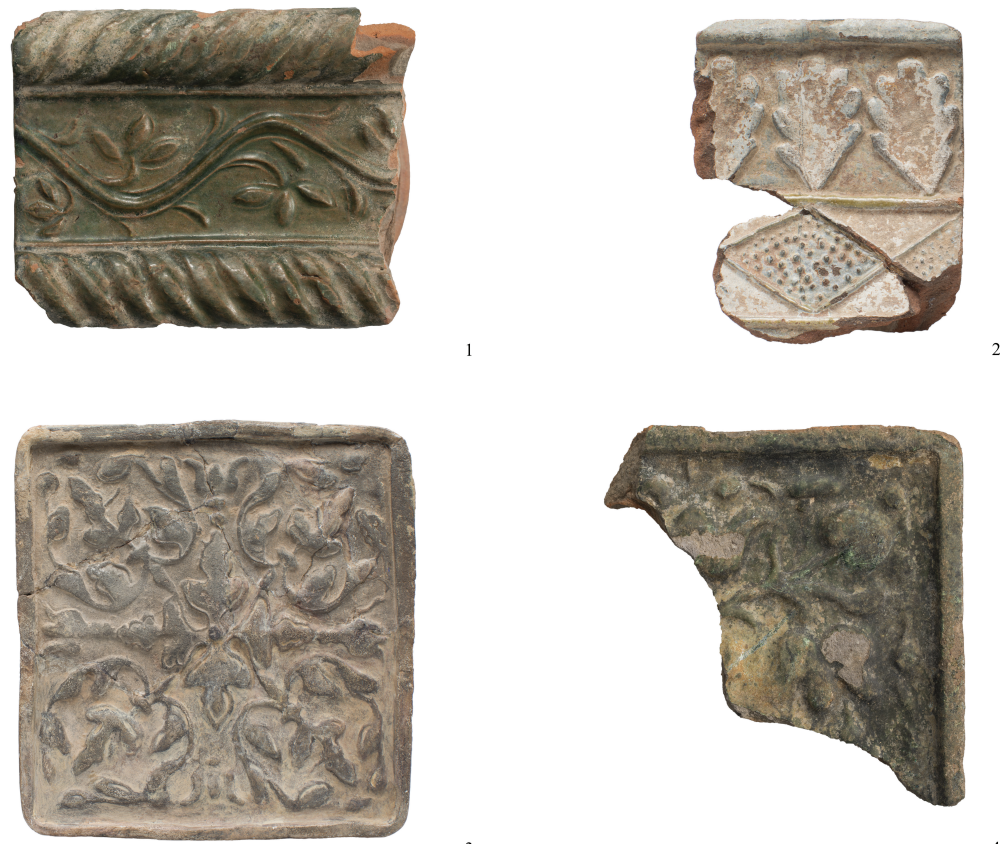

3

Рис. 17. 1. Дрогичин, изразец из второй половины 16. века. Размер - высота: 130 мм; ширина: 158 мм; глубина: 73 мм. 2. Мельник, изразец из второй половины 16. века. Размер - высота: 137 мм; ширина: 98 мм; глубина: 91 мм. 3. Мельник, изразец из второй половины 16. века - начала 17. века. Размер - высота: 193 мм; ширина: 181 мм; глубина: 59 мм. 4. Бельск, изразец из второй половины 16. века - начала 17. века. Размер - высота: 119 мм; ширина: 117 мм; глубина: 44 мм

Сл. 17. 1. Дрогичин, плочица из друге половине 16. века. Димензије - висина: 130 мм; ширина: 158 мм; дубина: 73 мм. 2. Мјелњик, плочица из друге половине 16. века. Димензије - висина: 137 мм; ширина: 98 мм; дубина: 91 мм. 3. Мјелњик, плочица из друге половине 16. века и почетка 17. века. Димензије - висина: 193 мм; ширина: 181 мм; дубина: 59 мм. 4. Бельск, плочица из друге половине 16. века почетка 17. века. Димензије - висина: 119 мм; ширина: 117 мм; дубина: 44 мм

\section{Изразцы с жанровыми сценами из дворянской жизни}

Одним из наиболее частых типов ренессансных изразцовых декоров являются портретные представления правителей и дворян. Интересным примером есть вид мужчины, одетого в ренессансную шубу с широким, выложенным воротником и широкими манжетами, играющего на волынке, найденный в замке в Мельнике (рис. 16: 1). Аналогические изразцы Болеславец над Просной (рис. 16: 2) (Żemigała 1987, рис. 98), Хробеж (MarciniakKajzer 2003, 298, рис. 1). 

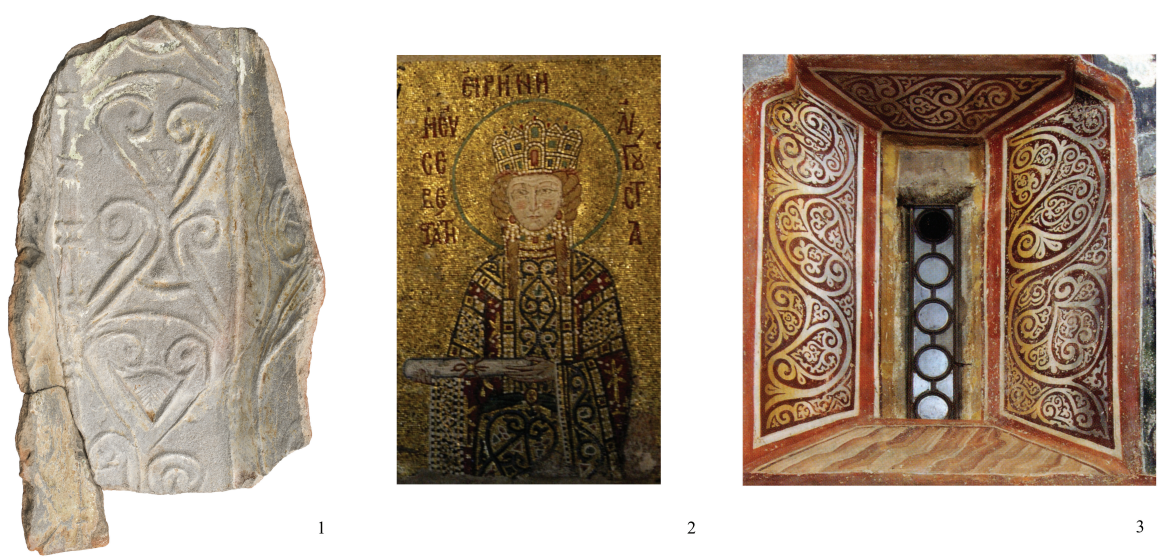

Рис. 18. 1. Тыкоцин, монастырь бернардинцев, изразец из 16. века. Размер - высота: 117 мм; ширина: 190 мм; глубина: 103 мм. 2. Агия София в Константинополе (современный Стамбул, Турция). Императрица Ирина, жена византийского императора Иоанна II Комнина, фрагмент мозаики (www.wikipedia.org.pl; доступ:

18. 03. 2021). 3. Монастырь Морача, Черногория, фрагмент фреска (Српска културна и духовна баштина, 5 2011, 32)

Сл. 18. 1. Тикоћин, бернардински манастир, плочица из 16 века. Димензије висина: 117 мм; ширина: 190 мм; дубина: 103 мм. 2. Света Софија у Цариграду (савремени Истанбул, Турска). Царица Ирина, супруга византијског цара Јована II Комнина, фрагмент мозаика (www.wikipedia.org.pl; приступљено: 18. 03. 2021).

3. Манастир Морача, Црна Гора, фрагмент фреске (Српска културна и духовна баштина, 52011,32 )

На лицевой пластине, найденной в Сураже, изображён молодой человек одет в ренессансную шубу, и шапку с пером, под аркадой и готическим пятилистником (рис. 16:3). Фрагмент изразца с таким представлением был найден в Дубне, Подляшье (Garas, Karwowska 2013, рис. 5). Изразец характеризуется чрезвычайно точным рисунком и тщательным разложением глазури. Аналогические изразцы (рис. 16: 4) из Худова (Tarasiński 2010, рис. 7), Бэндземысля (Czopek 1994, 97-100), Беч (Ślawscy 1994, 219, рис. 24), Вильна (Rackevicius 2012, 351, рис. 573-4), Вавеля, Кракова (PiątkiewiczDereniowa 1960, рис. 16), Болеславца над Просной (Żemigała 1987, рис. 97), Хробежа (Marciniak-Kajzer 2003, 299, pис. 2).

\section{Изразцы с растительным орнаментом}

Израцы из Бельска, Мельника и Тыкоцина (рис. 17, 18: 1) украшает растительный орнамент, закомпонованный по правилам четырёхчастной симметрии (рис. 17: 3, 4; 19: 3, 4). Интересным является наличие в центре 

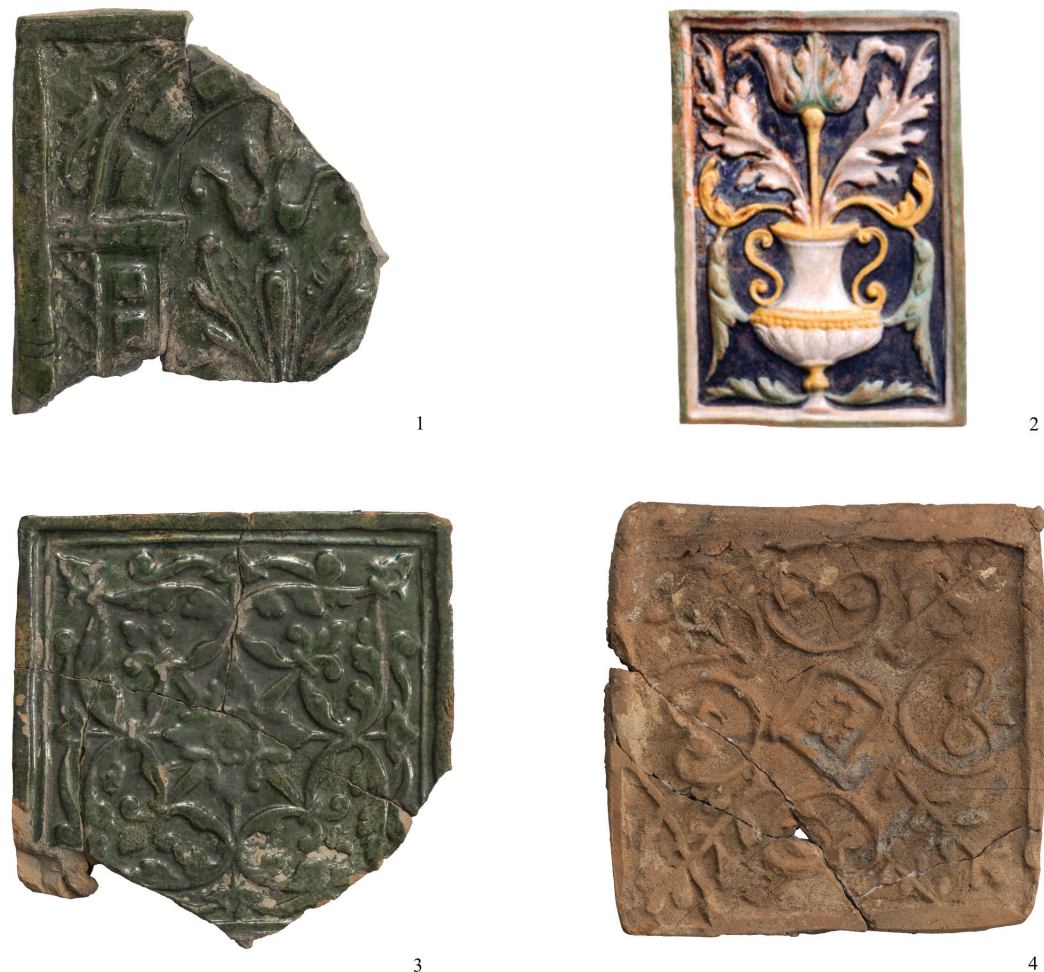

Рис. 19. 1. Тыкоцин, изразец из второй половины 16. века. Размер - высота: 151 мм; ширина: 141 мм; глубина: 44 мм. 2. Вильно, изразец из третьей третьи 16. века (Lietuovos didžiuju kunigaikščių rezidencija Vilniuje 2010, рис. 202). 3-4. Тыкоцин, изразцы из второй половины 16. века - начала 17. века. Размер - 3: высота: 206 мм; ширина: 206 мм; глубина: 96 мм; 4: высота: 165 мм; ширина: 170 мм; глубина: 67 мм

Сл. 19. 1. Тикоћин, плочица из друге половине 16. века. Димензије - висина: 151 мм; ширина: 141 мм; дубина: 44 мм. 2. Вилњус, плочица из треће трећине 16. века (Lietuovos didžiujų kunigaikščių rezidencija Vilniuje 2010, сл. 202). 3-4. Тикоћин, плочице из друге половине 16. века и почетка 17. века. Димензије - 3: висина: 206 мм; ширина: 206 мм; дубина: 96 мм; 4: висина: 165 мм; ширина: 170 мм; дубина: 67 мм

пластины многолепестковой розетки, от которой по диагонали отходили стилизованные растительные побеги, завершающиеся трилистником или бутоном (Бубенько 2007, 256). Отличительной особенностью является изразец из монастыря бернардинцев, который украшает византийско-русский, сербский орнаменты в виде стилизованных растительных побегов симметрически свергнутых (рис. 18: 1). Аналогический орнамент украшает одежду императрицы Ирины (жена византийского императора Иоанна II Комнина) 
представленной на мозаике с початку XII века находящейся в церкви Агия София в Константинополе (современный Стамбул) (рис. 18: 2) и стены сербского монастыря Морача (современная Черногория) (рис. 18: 3). Другой тип это ренессансный растительный декор в виде цветка лилии под аркадой, украшающий лицевую пластину печи дома в Тыкоцине (рис. 19: 1). Аналогическое изображение цветка есть на изразце из Вильна (Lietuovos didžiuju kunigaikščiu rezidencija Vilniuje 2010, 134), Лиды, Беларусь (Dziedzictwo archeologiczne Podlasia i Grodzieńszczyzny 2006, 59), Крэвы, Беларусь (Краўцэвіч 1991, рис. 31: 4), Заслаўя, Беларусь (Заяц 2001, 452, мал. 222: 8), и Онод, Венгрия (Tomka 2005, 238). На первую половину XVI века датируется дрогичинский изразец с стилизованной виноградной лозой (рис. 17: 1). Аналогический орнамент украшал виленский изразец (Rackevicius 282-3, рис. 279-281, 305, рис. 366, 379). Наряду с растительным декором в виде листьев дуба выступает геометрический орнамент - ромбы (рис. 17: 2).

Сосуществование на землях Подляшья - земель Западной Руси находящиеся в составе Великого княжества Литовского, двух цивилизаций: Восточной (византийско- русской) и Западной (латинской), двух христианских религий: Православной и Римско-католической, имело огромное влияние на формирование и развитие культурной традиции, как духовной так и материальной, которой изображением был между прочем орнамент печных изразцов. Эти предметы - глиняные плитки изразцов - являются ценной записью искусства, архитектуры, религиозной и ежедневной жизни русских и поляков во второй половине XV века - третьей четверти XVI века, в эпохе Ягеллонов. Эта чрезвычайно интересная этническая, культурная и цивилизационная мозаика до сегодняшнего дня продолжает существование во восточной части Подляшского воеводства, в северо-восточной Польше.

\section{ЛИТЕРАТУРА}

Апокалипсис, 2019, у Библия. Книги Священного Писания Ветхого и Нового Завета в русском переводе и приложениями. Москва: Российское Библейское Общество. Archiwum Glówne Akt Dawnych [AGAD], Archiwum Skarbu Koronnego [ASK] LVI, t. 4, k. 16-17.

Баранова, С.И. 2016. К вопросу о генезисе московского средневекового изразца, у Вестник Томского государственного университета. История 4: 53-60.

Беженару, Л. і Бакуменко, Л. 2003-2004. Зооморфологический анализ и типология изображений дракона в сцене со Святым Георгием, у Stratum plus. Macmepa Cредневековья, 5: 431-439. 
Brych, V. 2004. Kachle doby gotické, renesanční a raně barokní Výběrový katalog Národního muzea v Praze. Praha: Národní Muzeum.

Бубенько, T. 2007. Типология и хронология изразцов Витебского Замка XVI-XVIII веков, у Średniowieczne i nowożytne kafle. Regionalizmy-Podobieństwa-Różnice, ур. Dąbrowska M., Karwowska K., 253-272, Białystok.

Бузыкина, Ю. Н. і Трубицынт К. В. 2013. Ограничители на удилах коней на новгородских иконах вв., у Новгород и Новгородская земля. История и археология. Материяль научной конференщии, посвящённой 80-летию со дня рождения М. X. Алешковского, Великий Новгород, 22-24 января, 2013 г., ур. Янин В. Л., 27: 323-328, Великий Новгород.

Bukowski, W. i Michaluk, D. 2018. Najdawniejsze przywileje królewskiego miasta Bielska z XV i XVI wieku. Ciechanowiec - Warszawa.

Вениамин (Краснопевков-Румовский) Архиепископ, 1999. Новая Скрижаль или Объяснение о ичеркви, о литургии, и о всех службах и утварях ичерковных, Москва.

Garas, M. i Karwowska, H. 2013. Pozostałości urządzeń grzewczych, y Założenie rezydencjonalne Sapiehów w Dubnie, yp. Karwowska H., Andrzejewski A., 197-222, Białystok. Gil, A. 2015. Chrześcijaństwo kijowskie wobec idei jedności Kościołów. Prawosławie w Wielkim Księstwie Litewskim w drugiej połowie XV w., y Dzieje opactwa supraskiego. Acta Collegii Suprasliensis: XVIII, yp. Dobrowolski R., Zemło M., 9-19, Rzym-Lublin -Mińsk.

Gruia, A. M. 2006. Saint George on Medieval stove tiles from Transylvania, Moldavia and Wallachia. An Iconographical Approach, y Studia Patzinaka 3: 7-48.

Гупало, В. і Лосик, М. 2005. Давні кахлі з Дубна і Львова (за археологічними матеріалами), у Gotické a renesančné kachlice v Karpatoch, ур. J. Chovancec, 109-130, Trebišov.

Dąbrowska, M. 1987. Kafle i piece kaflowe w Polsce do końca XVIII wieku, Studia $i$ Materiaty z Historii Kultury Materialnej LVIII.

Dziedzictwo archeologiczne Podlasia i Grodzieńszczyzny 2006. Уp. Muzeum Podlaskie w Białymstoku, Białystok.

Dubas-Urwanowicz, E. 1995. Stosunek Korony do Unii z Litwą w latach 1562-1574, y Studia Podlaskie 5: 5-39.

Дук, Д. В. 2012. Изразцы XIV - начала XIX в., у Древнейшие города Беларуси: Полоик, 370-373, рис. 80-82. Мінск: Беларуская навука.

Dymek, K. 1995. Średniowieczne i renesansowe kafle ślaskie. Wrocław: Uniwersytet Wrocławski, Centrum Badań Śląskoznawczych i Bohemistycznych.

Евангелие от Иоанна, 2019, у Библия. Книги Священного Писания Ветхого и Нового Завета в русском переводе и приложениями, Москва: Российское Библейское Общество.

Івашкив, Г. 2005. Язичницкі та християнські мотиви і сюжети на давніх кахлях зі збірки Петра Лінинського, у Gotické a renesančné kachlice v Karpatoch, yp. J. Chovancec, 149-165. Trebišov. 
Jelscy wczoraj i dziś: (500-lecie rodziny Jelskich herbu Pielesz), 2007, yp. R. Zieliński, Донецк: Towarzystwo Kultury Polskiej Donbasu przy wsparciu Senatu RP i Fundacji „Pomoc Polakom na Wschodzie”.

Żemigała, M. 1987. Ogrzewanie piecowe na zamku w Bolesławcu nad Prosną XIVXVII w., y Acta Archaeologica Lodziensia 33. Wrocław: Zakład Narodowy im. Ossolińskich Wydawnictwo Polskiej Akademii Nauk.

Заяц, Ю. А. 2001. Кафля і кафляныя печы, у Археалогія Беларусі. Помнікі XIV-XVIII cmсm. Том 4, Мінск: Беларуская навука.

Znamierowski, A. 2003. Insygnia, symbole $i$ herby polskie. Warszawa.

Книга Бытия 2019, у Библия. Книги Священного Писания Ветхого и Нового Завета в русском переводе и приложениями. Москва: Российское Библейское Общество.

Kołodziejczyk, A. 2007. Podziały administracyjne i urzędy na Podlasiu i Grodzieńszczyźnie w XV-XVI wieku, y Puszcze wielkoksiążęe na północnym Podlasiu i zachodniej Grodzieńszczyźnie w XV-XVI wieku (podziały, administracja, stużby leśne $i$ wodne), yp. J. Śliwiński, 307-49. Olsztyn: wydawnictwo Uniwersytetu Warmińsko -Mazurskiego.

Koch, W. 2013. Style w architekturze. Arcydzieła budownictwa europejskiego od antyku po czasy współczesne, Warszawa.

Краўцэвіч, А. К. 1991. Гарады і замкі Беларускага Панямоння XIV-XVIII стст. Пляніроўка, Культурны слой, Мінск.

Lietuovos didžiųu kunigaikščiu rezidencija Vilniuje 2010, yp. V. Urbanavičius, Vilnius. Лоренц, Н. Ф. 1898. Орнамент всех времен и стилей: 100 таблиц с объяснительным текстом Н. Ф. Лоренца, Санкт-Петербург: Издание А. Ф. Девриена.

Лупиненко, Ю. М. 2010. Покрой пластинчатых доспехов на территории Руси в XII-XIII вв., у Матэрыялы па археалогіi Беларусі. Археалогія і гісторыя Гродзеншчыныл, 19: 100-109.

Манастир Морача, 5, 2011. Српска културна и духовна баштина. Светигора. Marciniak-Kajzer, A. 2003. Czy dwa piece Stanisława Tarnowskiego?, y Archaeologia Historica Polona 13: 295-306.

Marcu, D. 1994. Cahle medievale descoperite La Vad (Jud. Hunedoara), y Ars Transsilvaniae IV: $157-171$.

Mácelová, M. 2005. Ikonografia gotických kachlíc z banskobystrickej radnice, y Gotické a renesančné kachlice v Karpatoch, yp. J. Chovancec, 205-216, Trebišov.

Mironowicz, A. 2014. Rękopisy supraskie w zbiorach krajowych i obcych. Białystok.

Mironowicz, A. 2017. Związki kulturowe monasteru supraskiego z kulturą serbską w XVI wieku, y Elpis, 19: 149-168.

Moskal, K. 2012, Kafle w zbiorach Muzeum Historycznego Miasta Krakowa. Katalog Zbiorów Muzeum Historycznego Miasta Krakowa, Kraków.

Motowicka, A. i Zalewska, E. 2019. Wstęp. Katalog fresków, y Freski supraskie. Relikty XVI-wiecznego malarstwa postbizantyjskiego w kolekcji Muzeum Ikon w Supraślu, yp. A. Ruta, 349-379. Białystok. 
Niedźwiadek, R. 2007. Cztery zespoły kafli lubelskich z okresu od początku XVI do połowy XVII w., y Średniowieczne i nowożytne kafle. Regionalizmy - Podobieństwa Różnice, yp. M. Dąbrowska, H. Karwowska, 87-99, Białystok.

Niziołek, P. i Taranta, I. 2020. Kafle heraldyczne z Tykocina, y Biuletyn Konserwatorski Województwa Podlaskiego 26: 167-186.

Piątkiewicz-Dereniowa, M. 1960. Odkrycie najdawniejszych kafli wawelskich, y Studia do Dziejów Wawelu II: 490-492.

Pokryszkin, P. P. 2019. Cerkiew Zwiastowania w monasterze supraskim, y Freski supraskie. Relikty XVI-wiecznego malarstwa postbizantyjskiego w kolekcji Muzeum Ikon w Supraślu, yp. A. Ruta, 100-125. Białystok.

Pospieszna, B. 2013. Kafle i piece kaflowe w zbiorach Muzeum Zamkowego w Malborku, Seria: Katalogi zbiorów MZM, Malbork: Muzeum Zamkowe w Malborku.

Псалтир 2019, у Библия. Книги Священного Писания Ветхого и Нового Завета в русском переводе и приложениями. Москва: Российское Библейское Общество.

Rackevičius, G. 2012. Lietuvos Didžiosios Kunigaikštystès valdovų rūmai Vilniuje XVI a. Koklinių Krosnių Rekonstrukcija XVI a. koklių katalogas. Vilnius.

Rachuba, A. 2013. Dobra sapieżyńskie (linii kodeńska) - XV-XVII wiek, y Założenie rezydencjonalne Sapiehów w Dubnie, yp. Karwowska H., Andrzejewski A., 31-52, Białystok. Serbian Artistic Heritage in Kosovo and Metohija. Identity, significance and vulnerability, 2017. Уp. D. Otašević, Belgrade.

Словарь Библейского Богословия, 1974, Брюссель.

Соболева, Н. А. 2006. Очерки истории российской символики. От тамги до символов государственного суверенитета, Москва.

Sørensen, M. 2017. Domestic Comforts: Use of the Tile-stove in Castles of Medieval Denmark (AD 1200-1600). A Contextual Analysis of the Function and Socio-cultural Meanings of Tile-stoves in Aristocratic Homes Based on the Material from Selected Castles in Medieval Denmark. Master Thesis F2017.

Striškienè, E. 2007. XV-XVII a. grindų dangos archeologinių tyrimų duomenys ir istorinių grindų atkūrmo galimybès, y Vilniaus žemutinè pilis XIV a. - XIX a. pradžioje. 2005-2006 M. tyrimai, yp. Glemža L., 240-271, Vilnius.

Stupnicki, H. 1855. Herbarz polski i imionospis zasłużonych w Polsce ludzi wszystkich stanów i czasów; ułożony porządkiem alfabetycznym na podstawie Herbarza Niesieckiego i manuskryptów. Tom I. Lwów.

Ślawscy, G. i T. 1994. Garncarstwo i kaflarstwo w Bieczu od późnego średniowiecza do czasów współczesnych, y Garncarstwo i kaflarstwo na ziemiach polskich od późnego średniowiecza do czasów współczesnych. Materiały z konferencji, Rzeszów, 21-23 IX 1993, yp. A. Gruszczyńska, A. Targońska, 211-230. Rzeszów: Muzeum Okręgowe w Rzeszowie. Tarasiński, A. 2010. Najnowsze odkrycia kafli z zamku w Chudowie koło Gliwic, y Acta Universitatis Lodziensis, Folia Archaeologica 27: 121-134.

Tomka, G. 2005. Zwei Ofenkachelgruppen von den Burgen Ónod und Szendrő, y Gotické a renesančné kachlice v Karpatoch, yp. J. Chovancec, 231-240, Trebišov. 
Уваров, А.С. 1908, Християнская символика. Том 1. Символика древне-християнского периода, Москва.

Foster, M. 2004. History of the Maltese Cross, as used by the Order of St John of Jerusalem, http://www.lishfd.org/History/history_of_the_maltese_cross.htm.

Czopek, S. 1994. Renesansowe kafle z Będziemyśla, y Garncarstwo i kaflarstwo na ziemiach polskich od późnego średniowiecza do czasów współczesnych. Materiały z konferencji-Rzeszów, 21-23.IX.1993, yp. A. Gruszczyńska, A. Targońska, 95-120. Rzeszów: Muzeum Okręgowe w Rzeszowie. 


\title{
Ирина Таранта
}

Подласки музеј у Бјалистоку, Одељење за археологију, Бјалисток

\section{ОРНАМЕНТИКА КАСНИХ СРЕДЫОВЕКОВНИХ И РЕНЕСАНСНИХ ПЛОЧИЦА ПОДЛАСЈА - У ЗЕМЉИ ЗАПАДНЕ РУСИЈЕ У СКЛОПУ ВЕЛИКЕ КНЕЖЕВИНЕ ЛИТВАНИЈЕ}

\author{
Кључне речи: византијско-руски орнамент, руски орнамент, \\ готски орнамент, западна Русија, Подласко војводство
}

Орнамент је посебно широко уметничко подручје, врло занимљиво и озбиљно по историјском значају и по блиском, разноврсном односу са другим, ликовним уметностима (Лоренц 1898). Ако дубље сагледамо, схватићемо да украси нису случајни и произвољни, већ подређени, најпре духу и природи развоја уметности сваког народа, а онда и њиховој сврси (Лоренц 1898). Анализа украсних мотива касносредњовековних и ренесансних плочица у Подласју, у земљи западне Русије у склопу Великог војводства Литваније (данас источни део Подласког војводства, Пољска), омогућава проучавање утицаја и комуникације центара источне и западне Европе.

Избор представљеног материјала одредили су место истраживања (територија историјских земаља Подласја), стање очуваности, тематски разнолика орнаментика (верска, хералдичка, архитектонска итд.), као и хронологија - време (друга половина 15. - трећа трећина 16. века). Плочице су пронађене у различитим центрима: градовима (Белск, Драгичин, Сураж, Тикоћин), замку (Мјельик), манастирима (православни Супрасл и католички Тикоћин) те племићком поседу (Дубно). Оне представљају један од најбројнијих и најзанимљивијих материјала из овог периода у збирци Подласког музеја у Бјалистоку, у Одељењу за археологију.

У иконографији збирке плочица о којој се говори важно место заузимају верски предмети инспирисани Светим писмом (посебно Јеванђеље по Јовану и Књига откривења), чије је познавање било на високом нивоу. Хришћанска симболика пренета је уметничким језиком на глинене плоче ових производа. У византијско-руској, руској и српској уметности хришћанске идеје и предмети користе уметност у служби религије. Због прецизног прилагођавања украса одређеној врсти плочица (зид, венац, каиш), декор се складно уклапа у структуру сваког елемента пећи.

Историјске и културне специфичности ових земаља током позног средњег века-ренесансе (од друге половине 15. до треће трећине 16. века), 
када су постојале две цивилизације: византијско-руска и латинска, веома су утицале на теме декоративних елемената плочица, које нису биле само украс чисто уметничких вредности већ су одражавале човекове мисли и осећања у његовим двема главним сферама: сакралној и профаној. Овај изузетно занимљив етнички, културни и цивилизацијски мозаик опстаје до данас у источном делу Подласког војводства, на североистоку Пољске. 